\title{
DIFFERENTIATED INTRA- AND INTER-AGGREGATE WATER CONTENT MODELS OF MX-80 BENTONITE
}

Authors' postprint version of the paper published in Applied Clay Science:

Navarro V, Asensio L, De la Morena G, Pintado X and Yustres Á (2015)

Differentiated intra- and inter-aggregate water content models of MX-80 bentonite. Applied Clay Science 118:325-336.

doi: 10.1016/j.clay.2015.10.015 
1 DIFFERENTIATED INTRA- AND INTER-AGGREGATE WATER CONTENT

2 MODELS OF MX-80 BENTONITE

3

4 Vicente Navarro *a, Laura Asensio a , Gema De la Morena ${ }^{\mathrm{a}}$, Xavier Pintado ${ }^{\mathrm{b}}$ and Ángel

5 Yustres $^{\text {a }}$

$6{ }^{a}$ Geoenvironmental Group, Civil Engineering Department, University of Castilla-La

7 Mancha, Avda. Camilo José Cela s/n, 13071 Ciudad Real, Spain

$8{ }^{\mathrm{b}}$ B + Tech Oy, Laulukuja 4, 00420 Helsinki, Finland

$9 \quad$ *Corresponding author. Email address: vicente.navarro@uclm.es; Tel. +34926295300

10 ext. 3264; Fax +34926295391

\section{ABSTRACT}

The current research proposes a method for obtaining the intra-aggregate

(microstructural) and inter-aggregate (macrostructural) water content of MX-80

bentonite using data from water retention curves. Data associated with high suction

were used to define the microstructural water content model. By extrapolating this

model to low suction, microstructural and macrostructural water contents were separated to obtain a macrostructural water content model. Micro- and macrostructural water content models have been used to simulate an isotropic swelling test, thus illustrating the advisability of using a double and differentiated macro/micro description of the water content to characterise the hydro-mechanical behaviour of MX-80 bentonite.

\section{KEYWORDS}

Bentonite; double porosity; water content; disaggregated model; microstructure 


\section{INTRODUCTION}

27 According to experimental observations by various authors who have studied the fabric of compacted expansive clays, the pore-size distribution function of these materials generally displays a distinct bimodal character (see Delage et al., 1996, Romero et al., 1999, Lloret et al., 2003, Delage et al., 2006, Romero et al. 2011 and references therein). As established by Gens and Alonso (1992), Alonso et al. (1999), Sánchez et al. (2005), Musso et al. (2013) and Guimarães et al. (2013), among others, it is advisable to use double porosity models when simulating the thermo-hydro-chemo-mechanical behaviour of these materials. In these works, two structural levels are considered: the macrostructural level, which is composed of global arrangements of clay aggregates with pores between them (Sánchez et al., 2005), and the microstructural level, which corresponds to the intra-aggregate porosity. Gerke and van Genuchten (1993a, b) proposed a similar model to analyse the flow of water and solutes in a structured soil. In principle, the water located within the pores between aggregates (macrostructural water) might have a chemical potential that differs from that of the water stored inside the aggregates (microstructural water). In such a case, a diffusion-type process of mass exchange (Guimarães et al., 2013) will occur that might not be instantaneous and could play an important role in the time-dependent deformation of soils (see Wilson and Aifantis, 1982; Ghafouri and Lewis, 1996; Alonso et al., 1991; Gens et al. 2011). These transient processes also occur when water retention curves (WRCs) are characterised (Dueck, 2008). However, the water content is usually measured after the transient processes are finished and equilibrium in suction is reached (Delage, 2002). Still, even under equilibrium conditions, it is advisable to differentiate between the microstructural and macrostructural water content when simulating bentonite behaviour (Alonso et al., 2011; Gens et al., 2011). In this way, it is possible to determine the 
51 macrostructural void ratio and degree of saturation. The macrostructural void ratio constrains the macrostructural intrinsic permeability, and the macrostructural degree of saturation is required to obtain the macrostructural relative permeability. Relative and intrinsic permeabilities define the macrostructural advective flow, which is instrumental for correctly formulating the water mass balance. Thus, it is worthwhile to define differentiated hydraulic models of the microstructural and macrostructural water content.

The following sections discuss a procedure to obtain these models from WRCs. First, experimental data obtained for high suction values (greater than $20 \mathrm{MPa}$ ) are used to model the microstructural water content and void ratio. Second, this microstructural model is extrapolated for suctions of less than $20 \mathrm{MPa}$ to differentiate the microstructural and macrostructural water content. The results obtained in this manner are used to define the macrostructural water content model. Finally, the parameters deduced from the application of the model to the WRCs results were used to simulate an isotropic swelling test illustrating the scope and limitations of the proposed models.

\section{MATERIALS, METHODS AND EXPERIMENTAL DATA}

The WRCs of different batches of MX-80 bentonite were analysed in this work. First, a

Volclay MX-80 material whose physical properties correspond to those obtained by

Kumpulainen and Kiviranta (2010) (see Table 1) was tested in B+Tech's laboratory.

The isothermal $\left(25^{\circ} \mathrm{C}\right)$ paths in compacted samples under constant volume shown in Table 2 were used to determine the WRCs in an adapted oedometric cell. The vapour equilibrium technique was used to control suction during the tests. In this technique, control of the relative humidity $(R H)$ of the air surrounding the specimen allows 
75 imposition of a total suction $(s)$ because both magnitudes are related by the equation

$77 \quad[1] \quad s=\frac{R \cdot T \cdot \rho_{\mathrm{w}}}{M_{\mathrm{w}}} \operatorname{Ln}(R H)$

78 where $R$ is the universal gas constant, $T$ is the absolute temperature, $\rho_{\mathrm{w}}$ is the water density and $M_{\mathrm{w}}$ is the molar mass of water. Relative humidity is usually applied by varying the salinity of an aqueous solution (see, among others, Yahia-Aïssa, 1999; Dueck, 2004; Delage et al., 2008; Pintado et al., 2009). With this procedure, it is possible to obtain suction values of up to $1000 \mathrm{MPa}$ (Pintado et al., 2009).

Samples of $35 \mathrm{~mm}$ in diameter and approximately $16 \mathrm{~mm}$ high with different initial dry densities (from some $1400 \mathrm{~kg} / \mathrm{m}^{3}$ to almost $1700 \mathrm{~kg} / \mathrm{m}^{3}$ ) and water content values (between $4.6 \%$ and $6.2 \%$ hygroscopic water content under laboratory conditions) were tested (see Table 2). The total suction $s_{\mathrm{f}}$ was imposed in only one step by pumping relative-humidity-controlled air through an upper porous stone. The bottom porous stone was a no-flow boundary. The sample was assumed to reach a total suction that was close to the imposed suction when the swelling pressure reading (measured with a load cell installed on top of the sample) became stable. Moreover, the steady-state conditions were verified by measuring the $R H$ at the top and bottom of the sample using a capacitive hygrometer. A special piston and bottom plate were used to secure the hygrometer probes. After equilibrium was reached, the samples were extracted from the cell and the water content $w_{\mathrm{f}}$ (Table 2 ) was determined using the ASTM standard test method D2216-10 (ASTM, 2010). The values of $s_{\mathrm{f}}$ were measured using a chilledmirror dew-point psychrometer (Gee et al., 1992; Leong et al., 2003). The obtained

97 results are presented in Fig. 1.

98 In addition, the results from Dueck and Nilsson (2010) plotted in Fig. 2 were also analysed. The properties of the material used ("Wym") are listed in Table 1 (values 
adopted from Karnland et al., 2006). These tests were conducted at $20^{\circ} \mathrm{C}$ under free swelling conditions. In all cases, the vapour equilibrium technique was used to impose the total suction. Figure 2 also includes results from Wadsö et al. (2004) and Kahr et al. (1990) that were obtained in tests similar to those conducted by Dueck and Nilsson (2010). The total suction $(s)$ values shown in Fig. 2 were obtained using Eq. 1.

Finally, with respect to experimental work, an isotropic swelling test was performed in the laboratory at the University of Castilla-La Mancha. A cylindrical sample of the same MX-80 bentonite employed in the tests in Fig. 1 was uniaxially compacted. The sample that had a diameter of $50 \mathrm{~mm}$ and an initial height of $25 \mathrm{~mm}$. It had an initial bulk density of $2.03 \mathrm{~g} / \mathrm{cm}^{3}$ and an initial water content of $20 \%$. Using these values, and assuming the grain density of Table 1 , the initial dry density $\rho_{\mathrm{d}}$, total void ratio $e$ (total volume of voids per volume of mineral) and degree of saturation $S_{\mathrm{r}}$ were computed, as indicated in Table 3.

The test run for 65 days under isothermal conditions $\left(22^{\circ} \mathrm{C}\right)$. The sample was subjected to a constant cell pressure of 1.1 MPa in a triaxial apparatus with no contact between the top of the sample and the cell piston. Therefore, the test was performed under spherical stress conditions. A porous stone in contact with atmospheric conditions was placed on top of the sample. Free hydration with de-ionised water at atmospheric pressure was allowed at the bottom of the sample.

An automated system with two pressure/volume controllers was used for the test; one controller was used for the cell pressure and the other was connected to the bottom of the sample for the water injection pressure. No local strain transducers were used. The volume change data from the volume gauge in the cell controller were used to compute the volumetric strain $\varepsilon \mathrm{v}$. The cell deformation and the lab temperature variation were took into consideration to identify the volumetric strain trend of the soil. To this end, a 
125 detrending approach usually used when non-stationary time series are analysed was

126 applied to filter $\varepsilon_{\mathrm{V}}$ from the raw data (Salas et al., 1980). Although uniaxially

127 compacted samples tend to swell more in the axial direction, as the sample was held

128 under isotropic conditions, the axial strain $\varepsilon_{Z}$ was assumed to be $\varepsilon_{\mathrm{V}} / 3$. The vertical

129 swelling values plotted in Fig. 3 were derived using this procedure.

\section{MODEL DEVELOPMENT}

132 To separate the microstructural water content values from the total water content values

133 shown in Figs. 1 and 2, the total soil water content was assumed as the sum of the water

134 that partially fills the inter-aggregate voids ("macrostructural" water) and the water

135 stored inside the intra-aggregate porosity ("microstructural" water) (see Alonso et al.,

136 2011; Della Vecchia et al., 2012; and Casini et al., 2012, among others). According to

137 Or and Tuller (1999) and Tuller and Or (2005), it was accepted that capillary

138 contributions from the water held in the macropores dominated in the wetter range of

139 the WRC. In addition, the adsorptive contributions were considered dominant in the

140 dryer range of the curve, with the soil water content primarily occurring in the

141 micropores. The results obtained by Or and Tuller (1999) indicate that the capillary

142 contributions become negligible for a wide range of soil textures for suction values

143 greater than $10 \mathrm{MPa}$. Romero et al. (2011) identified the suction corresponding to

144 empty macropores and fully saturated micropores as $25 \mathrm{MPa}$ for FEBEX bentonite (for

145 a complete description of this material, see Enresa, 2000). Jacinto et al. (2009) found

146 that, for MX-80 bentonite, the dry density influences the water retention capacity for

147 suction less than approximately $30 \mathrm{MPa}$, which would be the lower limit for a region

148 dominated by adsorptive storage mechanisms (Romero et al., 2011). In the current

149 work, it has been assumed that the water content values from Figs. 1 and 2 are 
150 fundamentally associated with intra-aggregate water for suction values higher than 20

151 MPa.

152 Starting from a notably dry condition, the initial stages of hydration are associated with

153 crystalline swelling. Several authors have contributed valuable descriptions of this

154 process (Barshad, 1955; Pusch, 1983; Kahr et al., 1990; Laird, 1996; and Salles et al.,

155 2009), which is characterised in Fig. 4, adapted from Cases et al. (1992). Two possible

156 functional structures were considered for the description of this behaviour. First, the

157 application of the potential law proposed by Tuller and Or (2005) was analysed:

158

[2] $\quad w_{\mathrm{mC}}=\sqrt[3]{\frac{A}{6 \pi s_{\mathrm{m}}}} S \cdot \rho_{\mathrm{Wm}}$

159

where $w_{\mathrm{mC}}$ is the crystalline microstructural water content in percentage, $A$ is the

modulus of the Hamaker constant $\left(6 \cdot 10^{-20} \mathrm{~J}\right.$; Tuller and Or, 2005), $s_{\mathrm{m}}$ is the

161 microstructural suction, $S$ is the clay specific surface area (in units of $\mathrm{m}^{2} / \mathrm{kg}$ ) and the

162 microstructural water density $\rho_{\mathrm{wm}}$ is expressed in $\mathrm{kg} / \mathrm{m}^{3}$. Several works have shown that

163 the density of adsorbed water is greater than that of free water $\rho_{\mathrm{W}}$ (see, e.g., the review

164 in Hueckel, 1992). More recently, Jacinto et al. (2012) analysed the influence of water

165 density on the water retention properties of expansive clays. According to their work,

166 the density of adsorbed water in MX-80 bentonite at a suction of $100 \mathrm{MPa}$ is close to

$1671.17 \mathrm{~g} / \mathrm{cm}^{3}$. However, if instead of that density, the density of free water $\left(\rho_{\mathrm{W}}=1 \mathrm{~g} / \mathrm{cm}^{3}\right)$

168 is taken in the calculations, the volume of microstructural water could then be

169 overestimated by $17 \%$. For this reason, it is advisable to study the sensitivity of the

170 models to the value of $\rho_{\mathrm{Wm}}$. The evolution of water density with suction proposed by

171 Jacinto et al. (2012) can be used for this purpose. In such an exercise, it was verified

172 that the error derived from assuming $\rho_{\mathrm{Wm}}$ equals $\rho_{\mathrm{W}}$ does not substantially affect the

173 outcome of the calculations in the current work, and differences of less than $15 \%$ were 
174 obtained. Therefore, the free and adsorbed water densities were assumed to be equal for 175 modelling purposes (as in Tournassat and Appelo, 2011).

176 De-ionised water was used to prepare the samples of the tests in Figs. 1 and 2 (Dueck 177 and Nilsson, 2010; Pintado et al., 2013), and the samples were subsequently hydrated 178 by adding pure water from vapour condensation. This fact does not imply that osmotic 179 suction can be disregarded. The original osmotic suction given by the chemical 180 composition of the material independently of the salinity of the water added does not 181 necessarily have to be zero. Although this original value can be reduced when de182 ionised water is added, in many of the analysed cases the samples did not reach a high 183 degree of saturation, and no significant dilution took part. Therefore, the original 184 osmotic suction remained almost constant. However, in bentonite clays the structural 185 component (in the sense of Low, 1987) of suction is so high that the osmotic component 186 can be neglected. Hence, the microstructural suction (given in Pa units in Eq. 2) at 187 equilibrium with the macrostructural water can be calculated as (Navarro et al., 2013): [3] $s_{\mathrm{m}}=p+s_{\mathrm{M}}$ where $s_{\mathrm{M}}$ is the macrostructural matric suction $\left(s_{\mathrm{M}}=P_{\mathrm{G}}-P_{\mathrm{L}}\right.$, where $P_{\mathrm{G}}$ is the gas pressure and $P_{\mathrm{L}}$ is the pressure of macrostructural liquid) and $p$ is the net mean stress ( $p=p_{\mathrm{TOT}^{-}}$ $191 P_{\mathrm{G}}$, where $p_{\text {TOT }}$ is the mean stress).

192 In addition to the potential law of Tuller and Or (2005), the application of a van 193 Genuchten (1980) type curve (VG) was also considered to model $w_{\mathrm{mC}}$. This curve was 194 proposed by Durner (1994) to describe the retention characteristics of soils with 195 heterogeneous pore systems and was adopted by Gerke and van Genuchten (1993a) for 196 dual-porosity soils and Della Vecchia et al. (2014) for compacted clays. Similarly, a VG 197 model was employed to describe the microstructural degree of saturation in an analysis 
198 of clay soils by Alonso et al. (2011) and in a study of compacted silts by Casini et al.

199 (2012).

200 Cases et al. (1992) indicated that crystalline swelling is practically complete when the

201 suction reaches approximately $44 \mathrm{MPa}\left(R H\right.$ of $72 \%$ at $\left.20^{\circ} \mathrm{C}\right)$. For lower suctions, the

202 hydration dynamics change, and the processes known as "osmotic swelling" (or "double

203 layer swelling"; Laird, 1996) become more relevant. To model the increase in

204 microstructural water caused by this new wetting trend, the logarithmic law " $\Delta w_{\mathrm{mO}}$ ",

205 which is similar to that used by Dueck and Börgesson (2007), was adopted:

206

[4] $\Delta w_{\mathrm{mO}}=-B \cdot \operatorname{Ln}\left(\frac{s_{\mathrm{m}}+P_{\mathrm{ATM}}}{s_{\mathrm{mO}}+P_{\mathrm{ATM}}}\right)$

207 where $B$ is a material parameter and $s_{\mathrm{mO}}$ is the microstructural suction at which osmotic

208 swelling begins to play a significant role (a value of $40 \mathrm{MPa}$ has been assumed). Thus,

209 the microstructural water content was calculated as follows:

$210 \quad[5] \quad w_{\mathrm{m}}=w_{\mathrm{mC}}+\Delta w_{\mathrm{mO}}$

211 If one assumes that the increase in microstructural void space from the dry state is equal

212 to the increase in microstructural water, then the following relationship holds:

$213 \quad[6] \quad e_{\mathrm{m}}=G_{\mathrm{S}} \cdot w_{\mathrm{m}}$

214 where $G_{\mathrm{S}}=\rho_{\mathrm{S}} / \rho_{\mathrm{W}}$ is the specific gravity of the soil particles, $\rho_{\mathrm{S}}$ is the density of mineral

215 particles (see Table 1) and $e_{\mathrm{m}}$ is the microstructural void ratio (volume of voids in the

216 microstructure per volume of clay mineral). Therefore, the definition of the

217 microstructural water content directly implies the definition of a model of

218 microstructural porosity and vice versa. Eq. 5 can be written as follows in terms of the

219 microstructural void ratio:

220

[7]

$$
e_{\mathrm{m}}=e_{\mathrm{mC}}+\Delta e_{\mathrm{mo}}
$$


221 The VG model and Eqs. 2 and 4 can also be written using $e_{\mathrm{m}}$. In particular, if the latter

222 equation is written as a function of $e_{\mathrm{m}}$, the following equation is obtained for $s_{\mathrm{m}}$ less

223 than $40 \mathrm{MPa}$ :

$224 \quad[8] \quad \Delta e_{\mathrm{mO}}=-\kappa_{\mathrm{m}} \cdot \operatorname{Ln}\left(\frac{s_{\mathrm{m}}+P_{\mathrm{ATM}}}{s_{\mathrm{mO}}+P_{\mathrm{ATM}}}\right)$

225 This expression, where $\kappa_{\mathrm{m}}$ is a microstructural stiffness parameter, was utilised by

226 Sánchez et al. (2005), Alonso and Navarro (2005), Alonso et al. (2011) and Gens et al.

227 (2011) to define the volumetric behaviour of the microstructure.

228 Once the model for the microstructural water content was defined, it was used to

229 estimate $w_{\mathrm{m}}$ for suctions less than $20 \mathrm{MPa}$. The obtained values allowed to derive the

230 macrostructural water content $\left(w_{\mathrm{M}}\right)$ by subtracting the estimated $w_{\mathrm{m}}$ values from the

231 experimental water content ( $w$ ) values: $w_{\mathrm{M}}=w-w_{\mathrm{m}}$ (see Della Vecchia et al., 2012, for

232 example). The $w_{M}$ values obtained in this manner were used to define a model of the

233 macrostructural retention law. A VG model was also applied, and $s$ was used as a state

234 variable.

235 A double porosity model (Gens and Alonso, 1992; Alonso et al., 1999; Sánchez et al.,

236 2005; Guimarães et al., 2013) was adopted to simulate the swelling test in Fig. 3. In the

237 simulation, equilibrium between macrostructural and microstructural water was not

238 assumed: the water potentials in the two structural levels might be different, which leads

239 to an exchange of water between them (Gens et al., 2011). Therefore, a mass exchange

240 term $c_{\mathrm{m}}$ between the two levels was included when analysing the mass balance of both

241 micro and macrostructural water. Hence, the macrostructural water mass balance was

242 formulated as (Navarro et al., 2008):

243

[9] $\quad \frac{\partial m_{\mathrm{M}}}{\partial t}+\nabla \cdot\left(m_{\mathrm{M}} \cdot \mathbf{q}_{\mathrm{M}}\right)+c_{\mathrm{m}}=0$ 
244 where $m_{\mathrm{M}}=\left(\rho_{\mathrm{W}} \cdot S_{\mathrm{rM}} \cdot e_{\mathrm{M}}\right) /(1+e)$ is the mass of macrostructural water per unit volume,

$245 S_{\mathrm{rM}}$ is the macrostructural degree of saturation, $e_{\mathrm{M}}$ is the macrostructural void ratio, $\mathbf{q}_{\mathrm{M}}$

246 is the macrostructural water seepage, $\partial / \partial t$ is the time derivative and $\nabla \cdot$ is the divergence

247 operator. Although other authors have proposed first-order water transfer models (Gerke

248 and van Genuchten, 1993a, b; Musso et al., 2013), a non-linear formulation was

249 adopted to define $c_{\mathrm{m}}$ (Navarro et al., 2013):

250

[10] $\frac{c_{\mathrm{m}}}{\rho_{\mathrm{W}}}=H \cdot\left(\frac{p+s_{\mathrm{M}}}{s_{\mathrm{m}}}\right)^{C} \cdot\left(s_{\mathrm{m}}-\left(p+s_{\mathrm{M}}\right)\right)$

251 where the parameter $H$ defines the transfer coefficient at the end of the mass exchange

252 process (when $s_{\mathrm{m}}=s_{\mathrm{M}}+p$ ) and parameter $C$ describes the mass transfer change as $s_{\mathrm{m}}$

253 approaches $s_{\mathrm{M}}$. Consistent with the results obtained by Navarro et al. (2013) after

254 analysing an MX-80 bentonite test by Montes-H et al. (2003), the values $H=1.5 \cdot 10^{-8}$

$255(\mathrm{kPa} \cdot \mathrm{s})^{-1}$ and $C=0.4$ were assumed.

256 The macrostructural water seepage $\mathbf{q}_{\mathbf{M}}$ vector was calculated as follows:

257

[11] $\quad \mathbf{q}_{\mathrm{M}}=-\frac{k_{\mathrm{rM}} \cdot k_{\mathrm{iM}}}{\mu_{\mathrm{W}}} \cdot\left(\nabla P_{\mathrm{L}}+\rho_{\mathrm{W}} \cdot \mathrm{g} \cdot \nabla z\right)$

258 where $k_{\mathrm{rM}}$ is the relative permeability, $k_{\mathrm{iM}}$ is the isotropic intrinsic permeability, $\mu_{\mathrm{W}}$ is

259 the dynamic viscosity of water, $g$ is the gravity constant and $z$ is the vertical coordinate.

260 The Brooks and Corey (1964) and Burdine (1953) formulation with an exponent value

261 equal to 3 (Börgesson and Hernelind, 1999; Gens et al., 2011) was used to model the

262 relative permeability as a function of the macrostructural degree of saturation:

$263[12] \quad k_{\mathrm{rM}}=\left(S_{\mathrm{rM}}\right)^{3}$

264 An intrinsic permeability expressed as a function of the macrostructural porosity $\phi_{\mathrm{M}}$

$265=e_{\mathrm{M}} /(1+\mathrm{e})$ was adopted (Gens et al., 2011):

266

[13] $k_{\mathrm{iM}}=k_{\mathrm{MO}} \cdot \exp \left(b\left(\phi_{\mathrm{M}}-\phi_{\mathrm{MO}}\right)\right)$ 
267

268

269

270

271

272

273

274

275

276

277

278

279

280

281

282

283

284

285

286

287

where $b$ is a material parameter and $\phi_{\mathrm{MO}}$ is a reference macrostructural porosity for which the intrinsic permeability is $k_{\mathrm{MO}}$. Using the data from Karnland et al. (2006), the parameters $k_{\mathrm{MO}}=9.94 \cdot 10^{-21} \mathrm{~m}^{2}, b=9.18$ and $\phi_{\mathrm{MO}}=0.053$ were identified.

The microstructural water mass balance equation was formulated as follows:

[14] $\frac{\partial m_{\mathrm{m}}}{\partial \mathrm{t}}-c_{\mathrm{m}}=0$

where $m_{\mathrm{m}}=\left(\rho_{\mathrm{W}} \cdot e_{\mathrm{m}}\right) /(1+e)$ is the mass of microstructural water per unit volume. Similar to the immobile water of van Genuchten and Wierenga (1976), the microstructural water was considered linked to the soil skeleton.

The above formulation was implemented in the multiphysics partial differential equations solver COMSOL Multiphysics (Comsol AB, 2011) to simulate the isotropic swelling test. The numerical strategies described by Navarro et al. (2014b) were applied. The solution of Eqs. 9 and 14 allows calculation of the state variables $P_{\mathrm{L}}$ and $e_{\mathrm{m}}$.

\section{DETERMINATION OF MODEL PARAMETERS FROM WRCs RESULTS}

To analyse the validity of Eq. 2, the product $w_{\mathrm{m}} \cdot s_{\mathrm{m}}{ }^{1 / 3}$ is represented in Fig. 5a, as obtained with data from the tests of Fig. 2. Only data from suctions greater than $40 \mathrm{MPa}$ $\left(w=w_{\mathrm{m}}=w_{\mathrm{mC}}\right)$ were used. As shown, the relationship is not constant. According to Eq. 2 and as highlighted by Cases et al. (1992) and Salles et al. (2009), among others, this result appears to indicate that the clay specific surface area is not constant throughout the hydration process. Therefore, the data for $s_{\mathrm{m}}$ and $w_{\mathrm{m}}$ that were used in Fig. 5a are compared in Fig. $5 \mathrm{~b}$ with the model of $w_{\mathrm{m}}$ that results from introducing into Eq. 2 the variation of $S$ obtained by Salles et al. (2009) in their hydration analysis of a Namontmorillonite (see Fig. 5c). The fit is not satisfactory. 
291 Indeed, there is no reason to expect that the variation of $S$ from the analysis of Na-

292 montmorillonite in Salles et al. (2009) should exactly reproduce the variations of

293 specific surface area in the MX-80 bentonite studied in this work. If all of the values of

$294 w_{\mathrm{m}}$ and $s_{\mathrm{m}}$ from the tests of Fig. 2 are used, the value of $S$ linked to each $w_{\mathrm{m}}-s_{\mathrm{m}}$ point

295 can be found through Eq. 2, obtaining the results in Fig. 5c. The identified law is

296 different from that obtained by Salles et al. (2009). For suction values less than $40 \mathrm{MPa}$,

297 the specific surface area begins to show a greater dispersion, which appears to confirm

298 that a change in the hydration trend is produced near this value.

299 If reliable information on the evolution of $S$ is not available beforehand, then application

300 of Eq. 2 to obtain $w_{\mathrm{mC}}$ is not a simple task. Therefore, use of the VG model was

301 considered because its sigmoidal shape can approximate the characteristic curve shown

302 in Fig. 4. According to Eq. 6, the VG model was formulated in terms of the

303 microstructural void ratio as follows:

304

[15] $\quad e_{\mathrm{mC}}=\frac{e_{\mathrm{mCMAX}}}{\left(1+\left(\alpha_{\mathrm{m}} \cdot s_{\mathrm{m}}\right)^{n_{\mathrm{m}}}\right)^{l_{\mathrm{m}}}}$

305

where $e_{\mathrm{mCMAX}}$ is the microstructural void ratio associated with the crystalline swelling at

saturation, and $\alpha_{\mathrm{m}}$ and $l_{\mathrm{m}}$ are fitting parameters. The relationship $n_{\mathrm{m}}=1 /\left(1-l_{\mathrm{m}}\right)$ (van

307

Genuchten, 1980) was assumed to be valid. Using experimental values from Fig. 2

associated with suctions greater than $40 \mathrm{MPa}$, values of $e_{\mathrm{m}}$ (identified with $e_{\mathrm{mC}}$ ) were

derived with Eq. 6, and a least-squares method was applied to obtain the parameters of

310 Eq. 15 included in Table 4. Using these parameters, the fitting represented in Fig. 6 was

311 obtained, which satisfactorily reproduces the aimed suction range $\left(s_{\mathrm{m}}>40 \mathrm{MPa}\right)$.

312 As illustrated in Fig. 7, the same is not true when tests 3_10_20 and 5_64_10, also

313 performed by Dueck and Nilsson (2010) under free swelling conditions using the

314 vapour equilibrium technique, are modelled ("emC" curve). These tests are different 
315 from the 1_0_20 test because their initial bentonite water content was greater than zero 316 (10\% in 3_10_20 and 64\% in 5_64_10). An offset occurrs between the model and the 317 experimental values as if an "additional" microstructural void ratio (or microstructural 318 water content) were present, which is not accounted for in Eq. 15. Thus, as observed in 319 Fig. 4, a residual water content of $1.8 \%$ is identified for the Na-montmorillonite 320 analysed by Cases et al. (1992) under dry conditions. According to Eq. 6, this result 321 implies a microstructural void ratio $e_{\mathrm{mR}}$ of 0.048 . If this value is introduced into the law 322 for $e_{\mathrm{mC}}$ as follows:

323 [16] $e_{\mathrm{mC}}=e_{\mathrm{mR}}+\frac{e_{\mathrm{mCMAX}}}{\left(1+\left(\alpha_{\mathrm{m}} \cdot s_{\mathrm{m}}\right)^{n_{\mathrm{m}}}\right)^{m_{\mathrm{m}}}}$

324 the fit to the experimental data improves (Fig. 7, "emC+emR $(=0.048)$ " curve). This 325 improvement is even more noticeable if an identification problem is solved for the value 326 of $e_{\mathrm{mR}}$ that provides a better fitting to the experimental data (Fig. 7, "emC+emR_opt" 327 curve). An "optimal” value for $e_{\mathrm{mR}}$ of 0.093 was obtained (Table 4). Again, only 328 experimental data from Fig. 2 associated with suctions greater than $40 \mathrm{MPa}$ were used 329 to solve the identification problem.

330 Taking $e_{\mathrm{mR}}=0$, the $e_{\mathrm{m}}$ data from the tests in Fig. 2 were used once again to identify the 331 optimal value of the microstructural stiffness parameter $\kappa_{\mathrm{m}}$. However, in this case, 332 experimental values corresponding to the range between $20 \mathrm{MPa}$ and $40 \mathrm{MPa}$ were 333 used, and the satisfactory fit shown in Fig. 8 was obtained for $\kappa_{\mathrm{m}}=0.04$ (Table 4).

334 However, the quality of this fit has a limited scope because it is a consequence of the 335 solution to several parameter identification problems.

336 Conversely, the fit presented in Fig. 9 is more remarkable. In this figure, the model of $337 e_{\mathrm{m}}$ obtained from the parameters presented in Table 4 is compared with the experimental 338 results of Fig. 1. Because the parameters are based on the data of Fig. 2, they are 
339 independent of the experimental results of Fig. 1. For this reason, the obtained fit is

340 especially valuable and supports the microstructural model defined by the parameters of

341 Table 4 and Eqs. 7, 8 and 16. Acceptance of this model for both the free swelling tests

342 in Fig. 2 and the constant volume tests in Fig. 1 implies assumption of a one-to-one

343 relationship between $s_{\mathrm{m}}$ and $e_{\mathrm{m}}$ independent of the applied macroscopic strain

344 constraints, as certain authors have observed (see, among others, Villar, 2007; Romero

345 et al., 2011; Jacinto et al., 2012).

346 When $s_{\mathrm{m}}$ approaches zero, the modelled $e_{\mathrm{m}}$ moves gradually towards the value of 0.8

347 (Fig. 9). This value is slightly lower than 0.9, the value identified by Pusch et al., (1990)

348 and Bourg et al., (2006) for Na-bentonites and also by Romero et al. (2011) for an MX-

34980 bentonite. Nevertheless, this value is within the range that would result from

350 assuming that the adsorbed water has an equivalent thickness of two or three water

351 monolayers (see, among others, Sposito and Prost, 1982, and Cases et al., 1992) in a

352 situation of destructuration of bentonite aggregates into nearly individual sheets

353 (Neretnieks et al., 2009). In this case, $e_{\mathrm{m}}$ can be estimated with the ratio $t / t_{\mathrm{S}}$. If the sheet

354 thickness $t_{\mathrm{S}}$ is given a value of $1 \mathrm{~nm}$, and the thickness of each water layer $t$ is taken as

$3550.3 \mathrm{~nm}$, the obtained microstructural void ratio values are between 0.6 and 0.9. For this

356 reason, it was admitted as a working hypothesis that the extrapolation of the model of

$357 e_{\mathrm{m}}$ defined by Eqs. 7, 8 and 16 and the parameters in Table 4 is valid for estimation of

$358 e_{\mathrm{m}}$ for suctions less than $20 \mathrm{MPa}$.

359 After estimating $e_{\mathrm{m}}, w_{\mathrm{m}}$ was computed, and the macrostructural water content $w_{\mathrm{M}}$ was

360 derived by subtracting $w_{\mathrm{m}}$ from the total water content experimental values. In addition,

361 using the values of the final dry density $\rho_{\mathrm{d}}$ shown in Table 2 , the values of the total void

362 ratio $e$ were obtained, and using the estimated value of $e_{\mathrm{m}}$, the value of the

363 macrostructural void ratio $e_{\mathrm{M}}$ (volume of voids in the macrostructure per volume of 
364 mineral, $e=e_{\mathrm{M}}+e_{\mathrm{m}}$ ) was deducted. In this manner, the wetting experimental values of

365 the macrostructural degree of saturation $S_{\mathrm{rM}}$ presented in Fig. 10 ("SrM test data") were

366 calculated. The same figure shows the values of the "total" degree of saturation $S_{\mathrm{r}}$,

367 which were obtained from $w$ and $\rho_{\mathrm{d}}$ by assigning a unique characteristic curve to the

368 soil without differentiating between the macrostructural and microstructural water. As

369 expected, if there is no distinction between $w_{\mathrm{M}}$ and $w_{\mathrm{m}}$, the $S_{\mathrm{r}}$ values are greater than

$370 S_{\mathrm{rM}}$. The experimental results of Villar (2007) on the main wetting path are also

371 included in Fig. 10 for comparison purposes.

372 A VG model was fitted for both $S_{\mathrm{rM}}$ and $S_{\mathrm{r}}$, according to the following laws:

373

[17] $S_{\mathrm{rM}}=\left(1+\left(\frac{s}{P_{\mathrm{M}}}\right)^{\frac{1}{1-l_{\mathrm{M}}}}\right)^{-l_{\mathrm{M}}}$

374

[18] $S_{\mathrm{r}}=\left(1+\left(\frac{S}{P}\right)^{\frac{1}{1-l}}\right)^{-l}$

375 where $P_{\mathrm{M}}$ is the macrostructural air-entry pressure value. Parameters $P_{\mathrm{M}}, l_{\mathrm{M}}, P$ and $l$

376 were identified using a least-squares fitting procedure and the values indicated in Table

3775 were obtained. The relationships $n_{\mathrm{M}}=1 /\left(1-l_{\mathrm{M}}\right)$ and $n=1 /(1-l)$ (van Genuchten, 1980)

378 were assumed. The air-entry pressure values associated with $S_{\mathrm{rM}}$ were found to be

379 approximately $9 \mathrm{MPa}$, a value considerably closer to those indicated for the

380 macrostructure by other researchers, e.g., 0.5 MPa by Villar (2002) and 4.15 MPa by

381 Alonso et al. (2011), than the values of 24-26 MPa identified for the parameter $P$ of $S_{\mathrm{r}}$

382 (Table 5).

383

384

5. APPLICATION OF THE MODEL TO A SWELLING TEST 
385 Given the relevance of the water flow in a swelling test, the analysis of a test of this

386 type is a good method for illustrating the sensitivity of a water flow model to the use of

387 differentiated definitions of water content. Nonetheless, the results of such an exercise

388 depend not only on the adopted flux model but also on the stress-strain relationship

389 applied. This influence is reduced by analysing an isotropic swelling test under constant

390 mean stress, as that described in Section 2 (Fig. 3). In this case, after adopting the model

391 for $e_{\mathrm{m}}$ defined by Eqs. 7, 8 and 16 and the parameters shown in Table 4, the deformation

392 behaviour of the MX-80 in this type of isotropic test is determined by the model

393 selected to define $e_{\mathrm{M}}$. In this work, the same formulation as in the Barcelona Basic

394 Model (Alonso et al., 1990), which is widely accepted for the simulation of the

395 mechanical behaviour of bentonites (see, for instance, Lloret et al., 2003; Sánchez, et

396 al., 2005; Gens et al., 2011; Guimarães et al., 2013; Navarro et al., 2014a), was used for

397 modelling. The mechanical parameters of Table 6 were applied. With the exception of

398 the initial net mean yield stress $p_{\mathrm{O}}{ }^{*}$, these parameters were obtained by fitting

399 independent oedometric swelling tests performed by Sane et al. (2013) using the same

$400 \mathrm{MX}-80$ bentonite as that of the tests in Fig. 1 . The value of $p_{\mathrm{O}}{ }^{*}, 1800 \mathrm{kPa}$, was

401 estimated from the pressure applied during the uniaxial compaction of the sample, 8059

$402 \mathrm{kPa}$, using the proposal of Alonso et al. (2011).

403 In the numerical simulations, the gas pressure was assumed constant and equal to the

404 atmospheric pressure (0.1 MPa) throughout the sample. As done for the microstructural

405 suction (see Section 3), the osmotic component of the macrostructural suction was not

406 taken into account, and $s=s_{\mathrm{M}}$ was assumed. See Sedighi and Thomas, 2014, and

407 references therein, for examples in which osmotic suction is taken into account. The

408 lateral and upper surfaces were supposed to be impervious to water, and the liquid

409 pressure at the base surface was taken as equal to atmospheric pressure. With respect to 
410 the mechanical boundary conditions, a roller was applied to the sample base surface,

411 and a normal pressure of 1.1 MPa was applied to the remaining boundaries, assuming

412 isotropic strains.

413 Three different approaches were implemented in the partial differential equations solver

414 defined in Section 3 to analyse the sensitivity of the flow model to the proposed water

415 content models. In the first approach, which was adopted as a reference ("REF"), $s_{\mathrm{M}}$

416 was obtained with $P_{\mathrm{L}}$, and $S_{\mathrm{rM}}$ was calculated using Eq. 17 and the parameters of Table

417 5. Moreover, Eqs. 7, 8 and 16 and the parameters of Table 4 allowed determination of

$418 s_{\mathrm{m}}$ from $e_{\mathrm{m}}$. In this analysis, the descriptions of the macrostructural and microstructural

419 water content were considered separately, thus constituting a differentiated analysis.

420 The modelled vertical swelling values in Fig. 11 and $S_{\mathrm{rM}}$ values in Fig. 12a were

421 obtained. Even if available experimental water content values were desirable for a better

422 validation of the model, the fit of the vertical swelling values illustrated in Fig. 11

423 provides confidence for the first approach implemented ("REF") as well as for the

424 decision of adopting it as a reference. In addition, this satisfactory fit seems to confirm

425 the validity of assuming an isotropic swelling behaviour (last paragraph of Section 3).

426 Montes-Hernandez et al., 2006, describe a 21 MPa compaction pressure as "moderate",

427 and thus it seems reasonable to use the same adjective to describe the $8059 \mathrm{kPa}$ applied

428 in this case, especially if compared to the compaction pressures of 50-100 MPa applied

429 to MX-80 bentonites in other cases (see, among others, Johannesson and Börgesson,

430 1998; Johannesson, 2014; Börgesson and Hernelind, 2014). The compaction pressure

431 applied was probably moderate enough to limit the anisotropy of the sample, not being

432 large enough to invalidate the isotropic swelling hypothesis. Nevertheless, this

433 hypothesis might not be valid for cases with a higher compaction pressure. 
434 The "AP1" approach used the same mechanical model of the microstructure as that used

435 in REF (Eqs. 7, 8 and 16 together with the parameters of Table 4). However, instead of

436 using Eq. 17 to compute $S_{\mathrm{rM}}$, its value was calculated from $s_{\mathrm{M}}$ using Eq. 18

437 ("mistakenly" identifying $S_{\mathrm{rM}}$ with $S_{\mathrm{r}}$ ). Such calculations are performed when the

438 contribution of the microstructural water content is ignored in the experimental

439 determination of the soil characteristic curve. As a result, it is implicitly assumed that

440 the entire soil water content derives from macrostructural water. Using this retention

441 curve, the macrostructural water content is overestimated. To reduce this effect such

442 that the water mass can be balanced, suction values greater than the real values are

443 introduced in the calculations. Hence, using Eq. 17 in REF, a macrostructural initial

444 suction of $25499 \mathrm{kPa}$ was estimated for the initial conditions shown in Table 3, whereas

445 the initial suction estimated using the AP1 approach and Eq. 18 was $44303 \mathrm{kPa}$.

446 Because the initial suction is overestimated, a much larger final swelling was obtained

447 (see Fig. 11). To obtain a "correct" swelling (equal to that of REF) from the simulation,

448 an elastic stiffness for changes in suction (parameter $\kappa_{\text {So }}$ in Table 6) of 0.01 should be

449 adopted, which is significantly smaller than the reference value (0.05, Table 6). Such

450 corrections could lead to important calculation errors in subsequent simulations with

451 other geometries and boundary/initial conditions. In addition, even in the case under

452 analysis, and although the final swelling is fitted with $\kappa_{\mathrm{So}}=0.01$, the swelling evolution

453 is not satisfactorily reproduced (Fig. 11).

454 These errors can be reduced by considering that $S_{\mathrm{rM}}$ and $S_{\mathrm{r}}$ are related by the following 455 expression:

456

[19] $S_{\mathrm{rM}}=\frac{S_{\mathrm{r}} \cdot\left(e_{\mathrm{M}}+e_{\mathrm{m}}-e_{\mathrm{mR}}\right)-\left(e_{\mathrm{m}}-e_{\mathrm{mR}}\right)}{e_{\mathrm{M}}}$ 
457 The third and last approach considered in this work, known as "AP2," was conducted in this manner by assuming that only Eq. 18 was determined experimentally. However, a differentiated procedure was adopted because the contribution of $w_{\mathrm{m}}$ in $S_{\mathrm{r}}$ was considered. The $S_{\mathrm{r}}$ was calculated using $s_{\mathrm{M}}$ and Eq. 18 , and $S_{\mathrm{rM}}$ was subsequently deduced using Eq. 19. According to the data from Table 3, an initial suction value of $24127 \mathrm{kPa}$ was estimated, which is similar to the value obtained in REF (25499 $\mathrm{kPa})$.

Therefore, the final swelling obtained with AP2 matches the swelling obtained with REF, which is shown in Fig. 11. Furthermore, the modelled evolutions of the swelling strains are practically identical and obtain overlapping curves (Fig. 11).

However, differences in the macrostructural degree of saturation are observed (Fig. 12a). In Fig. 12b, these differences are shown to be less than $20 \%$ and reach a maximum value at the base of the sample during the initial portion of the test; when the macrostructural suction gradients are greater, the advective flux of the macrostructural water is larger, and the time variation of $s_{\mathrm{M}}$ is faster. According to Eq. $3, s_{\mathrm{m}}$ is equal to $p+s_{\mathrm{M}}$ in the equilibrium; then, the sample experiences a situation farthest from the equilibrium between macrostructural and microstructural water at the base of the sample and at the beginning of the test, as illustrated in Fig. 13. However, the imbalance is practically negligible. It is thus valid to use Eq. 18, which was obtained under equilibrium conditions.

Situations further from equilibrium are produced if the transfer coefficient $H$ increases from $1.5 \cdot 10^{-8}(\mathrm{kPa} \cdot \mathrm{s})^{-1}$ to $1.5 \cdot 10^{-11}(\mathrm{kPa} \cdot \mathrm{s})^{-1}$, the value identified by Alonso and Navarro (2005) in an analysis of the secondary compression of various clays. In this case, the difference between $s_{\mathrm{m}}$ and $p+s_{\mathrm{M}}$ increases considerably at the base of the sample at the beginning of the test. Nonetheless, even in this case, the differences in the swelling strain between the REF and AP2 approaches are always less than $10 \%$ (Fig. 14). 


\section{CONCLUSIONS}

484 The aim of this work is to define a method for obtaining differentiated hydraulic models

485 of the intra-aggregate (microstructural) and inter-aggregate (macrostructural) water

486 content of MX-80 bentonite using data from water retention curves (WRCs). An

487 additive (crystalline+osmotic swelling) approach is adopted to model the

microstructural void ratio (Equation 7), obtaining noteworthy fittings for suctions

greater than $20 \mathrm{MPa}$. For lower suction values, the additive model is extrapolated to

estimate the microstructural water content. This way, the macrostructural water content

is identified by subtracting the estimated microstructural water from the total water

492 content experimental data. The WRCs obtained in this manner (Fig. 10) could be

noticeably different from the total water content curves. If this difference is neglected

and the macrostructural water content is modelled using retention curves corresponding

to the total water content, excessively large values are obtained for the macrostructural

suction. Therefore, to fit the swelling strains obtained experimentally, the soil stiffness

497 for the changes in suction must be excessively reduced, which can lead to significant

498 errors in the subsequent predictions of the bentonite behaviour.

499 To avoid these errors, it is advisable to separate the macrostructural water content from

500 the total water content using Eq. 17. Nevertheless, it is also possible to use Eqs. 18 and

50119 to differentiate the macrostructural degree of saturation. Eq. 18 is obtained under

502 equilibrium conditions between macrostructural and microstructural water. Therefore,

503 the validity of the latter procedure is constrained by the fulfilment of the equilibrium

504 condition. For the analysed material, equilibrium is met, and therefore the two

505 differentiated approaches (separate macro and micro water contents, either using Eq. 17

506 or using Eqs. 18 and 19 together) produce comparable results (Figs. 11, 12a and 12b). 
507 These results are valid for the MX-80 bentonite analysed, but generalisation to other

508 types of clay is by no means obvious. Note that only wetting paths have been analysed,

509 and the dependence of the macrostructural water retention properties on the void ratio

510 has not been considered (see Della Vecchia et al., 2014, and references therein). In

511 addition, even if the results have shown a reduced sensitivity to the difference in density

512 between free and adsorbed water in the cases analysed in the current work, the same

513 might not apply in other cases (particularly for Ca-bentonites and for constant volume

514 experiments). However, despite these limitations, this analysis illustrates the

515 advisability of using differentiated approaches based on a double porosity retention

516 model to characterise the behaviour of MX-80 bentonites

517

518 ACKNOWLEDGEMENTS

519 This work was financed in part by B+Tech Oy (Finland) under a POSIVA Oy project.

520 In addition, the authors gratefully acknowledge the financial support provided by the

521 Spanish Ministry of Economy and Competitiveness under the Innocampus Program

522 2010. The authors also thank Oyinloye Femi Adesola and Oscar Merlo for collaboration

523 in the experimental work conducted to obtain Figs. 1 and 3, respectively.

524 


\section{APPENDIX A. LIST OF SYMBOLS}

A Modulus of the Hamaker constant

$B \quad$ Material parameter of the $\Delta w_{m o}$ model

$b \quad$ Material parameter

$C \quad$ Parameter that describes the mass transfer change as $s_{\mathrm{m}}$ approaches $s_{\mathrm{M}}$

$c_{m} \quad$ Mass exchange term between macrostructural and

microstructural water

Total void ratio

$e_{M} \quad$ Macrostructural void ratio

$e_{m} \quad$ Microstructural void ratio

$e_{m C} \quad$ Microstructural void ratio associated with crystalline swelling

$e_{\operatorname{mCMAX}} \quad$ Microstructural void ratio associated with the crystalline

swelling at saturation

$e_{\mathrm{mR}} \quad$ Additional microstructural void ratio

$G_{S} \quad$ Specific gravity of the soil particles

$g \quad$ Gravity constant

$H \quad$ Parameter that defines the transfer coefficient at the end of the mass exchange process

$K \quad$ Increase in cohesion with suction

$k_{i M} \quad$ Isotropic intrinsic permeability

$k_{\mathrm{MO}} \quad$ Intrinsic permeability when the macrostructural porosity is $\phi_{\mathrm{MO}}$

$k_{r M} \quad$ Relative permeability

$l \quad$ Fitting parameter of $S_{\mathrm{r}}$

$l_{M} \quad$ Fitting parameter of $S_{\mathrm{rM}}$ 
$l_{\mathrm{m}} \quad$ Fitting parameter of $e_{\mathrm{mC}}$

M Slope of the critical state line

$M_{w} \quad$ Molar mass of water

$m_{M} \quad$ Mass of macrostructural water per unit volume

$m_{\mathrm{m}} \quad$ Mass of microstructural water per unit volume

$n$

Fitting parameter of $S_{\mathrm{r}}$

$n_{\mathrm{m}} \quad$ Fitting parameter of $e_{\mathrm{mC}}$

$P \quad$ Total air-entry pressure value

$P_{\text {ATM }} \quad$ Atmospheric pressure

$P_{G} \quad$ Gas pressure

$P_{L} \quad$ Pressure of macrostructural liquid

$P_{M} \quad$ Macrostructural air-entry pressure value

$p$

Net mean stress

$p_{\mathrm{C}} \quad$ Reference stress

$p_{\mathrm{O}}{ }^{*} \quad$ Initial net mean yield stress

$p_{\text {REF }} \quad$ Material parameter used to define $\kappa_{\mathrm{S}}$

$p_{\text {TOT }} \quad$ Mean stress

$\boldsymbol{q}_{M} \quad$ Macrostructural water seepage

$R \quad$ Universal gas constant

RH Relative humidity

$r \quad$ Material parameter used to define the macrostructural soil compressibility

Clay specific surface area

$S_{m o} \quad$ Microstructural suction at which osmotic swelling begins to play a significant role 
Total degree of saturation

$S_{\mathrm{rM}} \quad$ Macrostructural degree of saturation

Total suction

$s_{f}$

Final total suction

$s_{M}$

Macrostructural matric suction

$s_{m}$

Microstructural suction

$s_{o} \quad$ Initial value of total suction

$T$

Absolute temperature

$t$

Approximate thickness of an adsorbed water layer

$t_{s}$

Approximate thickness of a montmorillonite sheet

$w$

Total water content

$w_{f}$

Water content at equilibrium with the final total suction $s_{f}$

$w_{M}$

Macrostructural water content

$w_{m}$

Microstructural water content

$w_{m C}$

Crystalline microstructural water content

$w_{o} \quad$ Initial value of water content

$z \quad$ Vertical coordinate

$\alpha_{\mathrm{i}}$

Material parameter used to define $\kappa$

$\alpha_{\mathrm{m}} \quad$ Fitting parameter of $e_{\mathrm{mC}}$

$\alpha_{\mathrm{Sp}} \quad$ Material parameter used to define $\kappa_{\mathrm{S}}$

$\alpha_{\mathrm{SS}} \quad$ Material parameter used to define $\kappa_{\mathrm{S}}$

$\beta \quad$ Material parameter used to define the macrostructural soil compressibility

$\Delta e_{m O} \quad$ Increase in microstructural void ratio caused by osmotic swelling 
$\Delta w_{m O} \quad$ Increase in microstructural water content caused by osmotic swelling

$\varepsilon_{v} \quad$ Volumetric strain

$\varepsilon_{z} \quad$ Axial (vertical) strain

$\kappa_{\mathrm{io}} \quad$ Material parameter used to define the macrostructural elastic stiffness for changes in net mean stress $(\kappa)$

$\kappa_{m} \quad$ Microstructural stiffness parameter

$\kappa_{\text {So }} \quad$ Material parameter used to define the macrostructural elastic stiffness for changes in suction $\left(\kappa_{\mathrm{S}}\right)$

$\lambda(0) \quad$ Slope of the virgin compression curve for saturated conditions

$\mu_{W} \quad$ Dynamic viscosity of water

$v \quad$ Poisson's ratio

$\rho_{d} \quad$ Dry density

$\rho_{n} \quad$ Bulk density

$\rho_{s} \quad$ Density of mineral particles

$\rho_{W} \quad$ Free water density

$\rho_{W m} \quad$ Microstructural water density

$\phi_{\mathrm{M}} \quad$ Macrostructural porosity

$\phi_{\mathrm{MO}} \quad$ Reference macrostructural porosity

$\partial / \partial t \quad$ Time derivative

$\nabla \cdot \quad$ Divergence operator

$\nabla \quad$ Gradient operator 
527

528 Alonso E.E. and Navarro V. (2005) Microstructural model for delayed deformation of

529 clay: loading history effects. Can Geotech J 42(2):381-392

530 Alonso E.E., Gens A., Josa A. (1990) A constitutive model for partially saturated soils.

531 Géotechnique 40(3):405-430

532 Alonso E.E., Gens A., Lloret A. (1991). Double structure model for the prediction of 533 long-term movements in expansive materials. In: Beer G., Booker J.R., Carter J.P. (eds.) 534 Computer methods and advances in geomechanics, vol. 1, pp. 541-548. Rotterdam, The 535 Netherlands: Balkema

536 Alonso E.E., Vaunat J., Gens A. (1999). Modelling the mechanical behaviour of 537 expansive clays. Eng Geol 54(1-2):173-183

538 Alonso E. E., Romero E., Hoffmann C. (2011) Hydromechanical behaviour of 539 compacted granular expansive mixtures: experimental and constitutive study.

540 Géotechnique 61(4):329-344. DOI: 10.1680/geot.2011.61.4.329

541 ASTM (2010). ASTM D2216-10, Standard Test Methods for Laboratory Determination 542 of Water (Moisture) Content of Soil and Rock by Mass, ASTM International, West 543 Conshohocken, PA. DOI: 10.1520/D2216-10

544 Barshad I. (1955) Adsorptive and swelling properties of clay-water system. In: Pask 545 J.A. and Turner M.D. (eds.) Proceedings of Clays and clay technology: 1st National 546 Conference on Clays and Clay Technology. Berkeley, California, July 21-25 1952. 547 California Division of Mines Bulletin 169. p. 70-77.

548 Börgesson L. and Hernelind J. (1999) Äspö Hard Rock Laboratory. Prototype 549 Repository. Preliminary modelling of the water saturation phase of the buffer and 550 backfill materials. SKB, International Progress Report IPR-00-11. Swedish Nuclear 551 Fuel and Waste Management Co. Available at: skb.se/upload/publications/pdf/ipr-00552 11.pdf, last accessed July 2015

553 Börgesson L. and Hernelind J. (2014) Modelling of bentonite block compaction. SKB, 554 Report P-14-10. Swedish Nuclear Fuel and Waste Management Co. Available at: 555 www.skb.com/publication/2719608/, last accessed October 2015

556 Bourg I.C., Sposito G., Bourg A.C.M. (2006) Tracer diffusion in compacted, water557 saturated bentonite. Clay Clay Miner 54(3):363-374.

558 Brooks R.M. and Corey A.T. (1964). Hydraulic properties of porous media. Hydrology 559 Paper no. 3. Fort Collins, Colorado, USA: Colorado State University

560 Burdine N.T. (1953). Relative permeability calculations from pore size distribution 561 data. Trans Am Inst Mining Metall Eng 198:71-78 
562 Cases J.M., Bérend I., Besson G., François M., Uriot J.P., Thomas F., Poirier J.E. 563 (1992) Mechanism of Adsorption and Desorption of Water Vapor by Homoionic 564 Montmorillonite. 1. The Sodium-Exchanged Form. Langmuir 8:2730-2739

565 Casini F., Vaunat J., Romero E., Desideri A. (2012) Consequences on water retention 566 properties of double-porosity features in a compacted silt. Acta Geotech 7:139-150.

567 DOI: $10.1007 / \mathrm{s} 11440-012-0159-6$

568 Comsol AB. (2011) COMSOL Multiphysics Reference Guide, version 4.2. COMSOL

569 Delage P. (2002) Experimental unsaturated soil mechanics: State-of-the-art report. In: 570 Juca JFT, De Campos TMP, Marino FAM (eds.) Proc. 3rd Int. Conf. on Unsaturated 571 Soils UNSAT'2002 (3):973-996. Recife, Brazil: Balkema

572 Delage P., Audiguier M., Cui Y.J., Howat M.D. (1996) Microstructure of a compacted 573 silt. Can Geotech J 33(1):150-158

574 Delage P., Marcial D., Cui Y.J., Ruiz X. (2006) Ageing effects in a compacted 575 bentonite: a microstructure approach. Géotechnique 56(5):291-304

576 Delage P., Romero E., Tarantino A. (2008) Recent developments in the techniques of 577 controlling and measuring suction in unsaturated soils. Proc. $1^{\text {st }}$ Eur. Conf. on 578 Unsaturated Soils, 33-52, E-UNSAT 2008, Durham, United Kingdom

579 Della Vecchia G., Jommi C., Romero E. (2012) A fully coupled elastic-plastic 580 hydromechanical model for compacted soils accounting for clay activity. Int J Numer 581 Anal Methods Geomech 37(5):503-535

582 Della Vecchia G., Dieudonné A.C., Jommi C., Charlier R. (2014) Accounting for 583 evolving pore size distribution in water retention models for compacted clay. Int $\mathbf{J}$ 584 Numer Anal Methods Geomech. DOI: 10.1002/nag.2326

585 Dueck A. (2004) Hydro-mechanical properties of a water unsaturated sodium bentonite. 586 Laboratory study and theoretical interpretation. Ph. D. Thesis, Lund University. Sweden

587 Dueck A. (2008) Laboratory results from hydro-mechanical tests on a water unsaturated 588 bentonite. Eng Geol 97(1-2):15-24

589 Dueck A. and Börgesson L. (2007) Model suggested for an important part of the hydro590 mechanical behaviour of a water unsaturated bentonite. Eng Geol 92:160-169

591 Dueck A. and Nilsson U. (2010) Thermo-Hydro-Mechanical properties of MX-80. 592 Results from advanced laboratory tests. SKB Technical Report TR-10-55. Swedish 593 Nuclear Fuel and Waste Management Co. Available at:

594 www.skb.se/upload/publications/pdf/TR-10-55.pdf, last accessed July 2015 
595 Durner W. (1994) Hydraulic conductivity estimation for soils with heterogeneous pore 596 structure. Water Resour Res 30(2):211-223

597 Edlefsen N.E. and Anderson A.B.C. (1943) Thermodynamics of soil moisture.

598 Hilgardia 15(2):31-298

599 Enresa (2000) FEBEX project. Full-scale engineered barriers experiment for a deep 600 geological repository for high level radioactive waste in crystalline host rock. Final 601 Report. PT 01/00. Madrid, Spain: Empresa Nacional de Residuos Radioactivos.

602 Available at:

603 www.enresa.es/publicaciones_y_audiovisuales/documentacion/pdf_febex_project_full, 604 last accessed July 2015

605 Gee G.W., Campbell M.D., Campbell G.S., Campbell J.H. (1992) Rapid measurement 606 of low soil water potentials using a water activity meter. Soil Sci Soc Am J 56:1068$607 \quad 1070$

608 Gens A. and Alonso E.E. (1992) A framework for the behavior of unsaturated 609 expansive clays. Can Geotech J 29(6):1013-1032

610 Gens A., Valleján B., Sánchez M., Imbert C., Villar M.V., Van Geet M. (2011)

611 Hydromechanical behaviour of a heterogeneous compacted soil: experimental 612 observations and modelling. Géotechnique 61(5): 367-386. DOI:

613 10.1680/geot.SIP11.P.015

614 Gerke H.H. and van Genuchten M.T. (1993a) A dual-porosity model for simulating the 615 preferential movement of water and solutes in structured porous media. Water Resour 616 Res 29(2):305-319

617 Gerke H.H. and van Genuchten M.T. (1993b) Evaluation of a first-order water transfer 618 term for variably saturated dual-porosity flow models. Water Resour Res 29(4):12256191238

620 Ghafouri H.R. and Lewis R.W. (1996) A finite element double porosity model for 621 heterogeneous deformable porous media. Int J Numer Anal Methods Geomech 622 20(11):831-844

623 Guimarães L.N., Gens A., Sánchez M., Olivella S. (2013). A chemo-mechanical 624 constitutive model accounting for cation exchange in expansive clays. Géotechnique 625 63(3):221-234. DOI: 10.1680/geot.SIP13.P.012

626 Hueckel T.A. (1992) Water-mineral interaction in hygromechanics of clays exposed to 627 environmental loads: a mixture-theory approach. Can Geotech J 29(6):1071-1086 
628 Jacinto A.C., Villar M.V., Gómez-Espina R., Ledesma A. (2009) Adaptation of the van 629 Genuchten expression to the effects of temperature and density for compacted

630 bentonites. Appl Clay Sci 42:575-582

631 Jacinto A.C., Villar M.V., Ledesma A. (2012) Influence of water density on the water632 retention curve of expansive clays. Géotechnique 62(8):657-667

633 Johannesson L-E., Börgesson L. (1998) Compaction of bentonite blocks. Development 634 of techniques for production of blocks with different shapes and sizes. SKB, Report R635 99-12. Swedish Nuclear Fuel and Waste Management Co. Available at:

636 www.skb.se/upload/publications/pdf/R-99-12.pdf, last accessed October 2015

637 Johannesson L-E. (2014) Manufacturing of buffer and filling components for the Multi 638 Purpose Test. SKB, Report P-14-07. Swedish Nuclear Fuel and Waste Management Co. 639 Available at: www.skb.se/upload/publications/pdf/P-14-07.pdf, last accessed October $640 \quad 2015$

641 Kahr G., Kraehenbuehl F., Stoeckli H.F., Müller-Vonmoos M. (1990) Study of the 642 water-bentonite system by vapour adsorption, immersion calorimetry and X-ray 643 techniques: II. Heats of immersion, swelling pressures and thermodynamic properties. 644 Clay Miner 25:499-506

645 Karnland O., Olsson S., Nilsson U. (2006) Mineralogy and sealing properties of various 646 bentonites and smectite-rich clay minerals. SKB Technical Report TR-06-30. Swedish 647 Nuclear Fuel and Waste Management Co. Available at:

648 www.skb.se/upload/publications/pdf/TR-06-30.pdf, last accessed July 2015

649 Kumpulainen S. and Kiviranta L. (2010) Mineralogical and chemical characterization of 650 various bentonite and smectite-rich clay materials. Part A: Comparison and 651 development of mineralogical characterization methods. Part B: Mineralogical and 652 chemical characterization of clay materials. Posiva Working Report 2010-52. Available 653 at: www.posiva.fi/files/3098/WR_2010-52_Korjattu_17.6.13.pdf, last accessed July 6542015

655 Laird D.A. (1996) Model for crystalline swelling of 2:1 phyllosilicates. Clay Clay 656 Miner 44(4):553-559

657 Leong E.C., Tripathy, S., Rahardjo H. (2003) Total suction measurement of unsaturated 658 soils with a device using chilled-mirror dew-point technique. Gèotechnique 53(2): 173 $659 \quad 182$

660 Lloret A., Villar M.V., Sánchez M., Gens A., Pintado X., Alonso E.E. (2003)

661 Mechanical behaviour of heavily compacted bentonite under high suction changes.

662 Géotechnique 53(1):27-40 
663

664

665

666

667

668

669

670

671

672

673

674

675

676

677

678

679

680

681

682

683

684

685

686

687

688

689

690

691

692

693

694

695

696

697

Low P.F. (1987) Structural component of the swelling pressure of clays. Langmuir 3(1):18-25. DOI: 10.1021/la00073a004

Montes-H G., Duplay, J. Martinez, L. Mendoza, C. (2003) Swelling-shrinkage kinetics of MX80 bentonite. Appl Clay Sci 22(6): 279-293

Montes-Hernandez G., Duplay J., Géraud Y., Martinez L. (2006) Several textural properties of compacted and cation-exchanged bentonite. J Phys Chem Solids 67(8): 1769-1174

Musso G., Romero E., Della Vecchia G. (2013) Double structure effects on the chemohydro-mechanical behaviour of compacted active clay. Géotechnique 63(3):206-220. DOI: 10.1680/geot.SIP13.P.011

Navarro V., Barrientos V., Yustres Á., Delgado J. (2008) Settlement of embankment fills constructed of granite fines. Comput Geosci 34(8):978-992

Navarro V., Asensio L., Yustres Á., Pintado X., Alonso J. (2013) Volumetric deformability and water mass exchange of bentonite aggregates. Eng Geol. DOI: 10.1016/j.enggeo.2013.09.011

Navarro V., Asensio L., Yustres Á., Pintado X., Alonso J. (2014a) An elastoplastic model of bentonite free swelling. Eng Geol 181:190-201. DOI:

10.1016/j.enggeo.2014.07.014

Navarro V., Asensio L., Alonso J., Yustres Á., Pintado X. (2014b) Multiphysics implementation of advanced soil mechanics models. Comput Geotech 60:20-28. DOI: 10.1016/j.compgeo.2014.03.012

Neretnieks I., Liu L., Moreno L. (2009) Mechanisms and models for bentonite erosion. SKB Technical Report TR-09-35. Svensk Kärnbränslehantering AB, Swedish Nuclear Fuel and Waste Management Co. Available at:

www.skb.se/upload/publications/pdf/TR-09-35.pdf, last accessed July 2015Or D. and Tuller M. (1999) Liquid retention and interfacial area in variably saturated porous media: Upscaling from single-pore to sample-scale model. Water Resour Res 35(12):3591- 3606

Pintado X., Lloret A., Romero E. (2009) Assessment of the use of the vapour equilibrium technique in controlled-suction tests. Can Geotech J 46(4):411

Pintado X., Mamunul H.M., Martikainen J. (2013) Thermo-hydro-mechanical tests of buffer material. Posiva Working Report 2012-49. Available at: www.posiva.fi/files/3385/POSIVA_2012-49.pdf, last accessed July 2015

Pusch R. (1983) Stability of bentonite gels in crystalline rock. Physical aspects. SKBFKBS Technical Report TR-83-04. Svensk Kärnbraänsleförsörjning AB/ Avdelning 
698 KBS. Available at: www.skb.se/upload/publications/pdf/TR83-04webb.pdf, last

699 accessed July 2015

700 Pusch R., Karnland O., Hökmark H. (1990) GMM - A general microstructural model

701 for qualitative and quantitative studies of smectite clays. SKB Technical Report TR-90-

702 43. Svensk Kärnbränslehantering AB; Swedish Nuclear Fuel and Waste Management

703 Co. Available at: www.skb.se/upload/publications/pdf/TR90-43_inlaga.pdf, last

704 accessed July 2015.

705 Romero E., Gens A., Lloret A. (1999) Water permeability, water retention and

706 microstructure of unsaturated compacted Boom clay. Eng Geol 54(1-2):117-127

707 Romero E., Della Vecchia G., Jommi C. (2011) An insight into the water retention

708 properties of compacted clayey soils. Géotechnique 61(4):313-328. DOI:

709 10.1680/geot.2011.61.4.313

710 Salas J.D., Delleur J.W., Yevjevich V.M., Lane, W.L. (1980) Applied modeling of

711 hydrologic time series. Water Resources Publications, 484 pp, Littleton, Colorado

712 Salles F., Douillard J.M., Denoyel R., Bildstein O., Jullien M., Beurroies I., van

713 Dammed H. (2009) Hydration sequence of swelling clays: Evolutions of specific

714 surface area and hydration energy. J Colloid Interface Sci 333:510-522

715 Sánchez M., Gens A., Guimarães L.N., Olivella S. (2005) A double structure

716 generalized plasticity model for expansive materials. Int J Numer Anal Methods

717 Geomech 29(8):751-787

718 Sane P., Laurila T., Olin M., Koskinen K. (2013) Current status of mechanical erosion 719 studies of bentonite buffer. Posiva Report 2012-45. Available at:

720 www.posiva.fi/files/3349/POSIVA_2012-45.pdf, last accessed October 2015.

721 Sedighi M. and Thomas H.W. (2014) Micro porosity evolution in compacted swelling 722 clays-A chemical approach. Appl Clay Sci 101:608-618

723 Sposito G. and Prost R. (1982) Structure of water adsorbed on smectites. Chem Rev

724 82(6):553-573

725 Tournassat C. and Appelo C.A.J. (2011) Modelling approaches for anion-exclusion in 726 compacted Na-bentonite. Geochim Cosmochim Acta 75(13):3698-3710

727 Tuller M. and Or D. (2005) Water films and scaling of soil characteristic curves at low 728 water contents. Water Resour Res 41, W09403. DOI:10.1029/2005WR004142

729 van Genuchten M.T. (1980) A closed-form equation for predicting the hydraulic

730 conductivity of unsaturated soils. Soil Sci Soc Am J 44(5):892-898 
731 van Genutchen M.T. and Wierenga P.J. (1976) Mass transfer studies in sorbing porous

732 media I. Analytical solutions. Soil Sci Soc Am J 40(4):473-480

733 Villar M.V. (2002) Thermo-hydro-mechanical characterisation of a bentonite from

734 Cabo de Gata. A study applied to the use of bentonite as sealing material in high level 735 radioactive waste repositories. PT 04/02. Madrid, Spain: Empresa Nacional de Residuos

736 Radioactivos. Available at: www.enresa.es/files/multimedios/PT04-02.pdf, last

737 accessed July 2015

738 Villar M.V. (2007) Water retention of two natural compacted bentonites. Clay Clay 739 Miner 55(3):311-322

740 Wadsö L., Svennberg K., Dueck A. (2004) An experimentally simple method for 741 measuring sorption isotherms. Dry Technol 22:2427-2440

742 Wilson R. and Aifantis E. (1982) On the theory of consolidation with double porosity.

743 Int J Eng Sci 20(9)1009-1035

744 Yahia-Aïssa M. (1999) Comportement hydromécanique d'une argile gonflante 745 fortement compactée. PhD Thesis. Ècole Nationale des Ponts et Chaussées, Paris, 746 France 
Table 1. Main properties of the MX-80 bentonite batches studied in this work. Data from Kumpulainen and Kiviranta (2010).

\begin{tabular}{|c|c|c|}
\hline & Volclay MX-80 & Wym \\
\hline Smectite & 76.3 & 81.4 \\
\hline Illite & 1.8 & 0.8 \\
\hline Calcite & 0.7 & 0.2 \\
\hline Cristobalite & 0.6 & 0.2 \\
\hline Gypsum & 1.2 & 0.9 \\
\hline Hematite & 0.4 & 0.4 \\
\hline Plagioclase & 2.3 & 3.5 \\
\hline Pyrite & 0.8 & 0.6 \\
\hline Quartz & 4.8 & 3.0 \\
\hline CEC (eq/kg) & 0.89 & 0.86 \\
\hline $\mathrm{Na}^{+} / \mathrm{K}^{+} / \mathrm{Ca}^{2+} / \mathrm{Mg}^{2+}(\mathrm{eq} / \mathrm{kg})$ & $0.60 / 0.02 / 0.19 / 0.07$ & $0.74 / 0.02 / 0.18 / 0.07$ \\
\hline Grain density $\mathrm{g} / \mathrm{cm}^{3}$ & 2.78 & 2.78 \\
\hline
\end{tabular}


Table 2. Tests conducted by B+Tech (Pintado et al., 2013). Symbols $w_{\mathrm{o}}$ and $s_{\mathrm{o}}$ define the initial water content and total suction values, respectively; $\mathrm{d}$ is the water content and $w_{\mathrm{f}}$ is the water content at equilibrium with the final total suction $s_{\mathrm{f}}$.

\begin{tabular}{|c|c|c|c|c|c|}
\hline Test ID & $w_{\mathrm{o}}(\%)$ & $s_{\mathrm{o}}(\mathrm{MPa})$ & ${ }_{\mathrm{d}}\left(\mathrm{kg} / \mathrm{m}^{3}\right)$ & $w_{\mathrm{f}}(\%)$ & $s_{\mathrm{f}}(\mathrm{MPa})$ \\
\hline \multirow{6}{*}{$091218 \mathrm{a}$} & \multirow{6}{*}{6.2} & \multirow{6}{*}{204.1} & 1576 & 3.0 & 288.1 \\
\hline & & & 1682 & 3.3 & 287.9 \\
\hline & & & 1522 & 10.6 & 89.4 \\
\hline & & & 1530 & 16.0 & 54.2 \\
\hline & & & 1529 & 15.0 & 60.9 \\
\hline & & & 1544 & 24.9 & 13.3 \\
\hline \multirow{6}{*}{$100111 b$} & \multirow{6}{*}{4.6} & \multirow{6}{*}{263.0} & 1622 & 3.1 & 267.5 \\
\hline & & & 1587 & 3.6 & 254.7 \\
\hline & & & 1543 & 9.5 & 95.9 \\
\hline & & & 1510 & 12.7 & 71.1 \\
\hline & & & 1539 & 13.3 & 68.6 \\
\hline & & & 1472 & 16.9 & 44.9 \\
\hline \multirow{6}{*}{$100208 \mathrm{a}$} & \multirow{6}{*}{5.1} & \multirow{6}{*}{204.8} & 1655 & 4.2 & 270.2 \\
\hline & & & 1661 & 6.7 & 177.0 \\
\hline & & & 1461 & 9.6 & 101.8 \\
\hline & & & 1446 & 15.7 & 56.9 \\
\hline & & & 1559 & 11.2 & 79.1 \\
\hline & & & 1576 & 20.8 & 25.5 \\
\hline \multirow{6}{*}{$100222 a$} & \multirow{6}{*}{5.5} & \multirow{6}{*}{231.9} & 1589 & 8.6 & 99.7 \\
\hline & & & 1638 & 11.1 & 80.4 \\
\hline & & & 1578 & 13.2 & 71.7 \\
\hline & & & 1539 & 15.1 & 56.6 \\
\hline & & & 1580 & 18.0 & 40.4 \\
\hline & & & 1603 & 19.6 & 28.1 \\
\hline
\end{tabular}


Table 3. Initial conditions of the MX-80 sample used in the isotropic swelling test.

\begin{tabular}{ll}
\hline$w(\%)$ & 20 \\
$\mathrm{n}\left(\mathrm{g} / \mathrm{cm}^{3}\right)$ & 2.03 \\
${ }_{\mathrm{d}}\left(\mathrm{g} / \mathrm{cm}^{3}\right)$ & 1.692 \\
$e^{S_{\mathrm{r}}}$ & 0.646 \\
\hline
\end{tabular}


Table 4. Parameters identified to characterise the microstructural void ratio using the data of Fig. 2.

\begin{tabular}{lr}
\hline$e_{\mathrm{mR}}$ & 0.093 \\
$e_{\mathrm{mCMAX}}$ & 0.480 \\
$\alpha_{\mathrm{m}}\left(\mathrm{MPa}^{-1}\right)$ & 0.016 \\
$l_{\mathrm{m}}$ & 0.612 \\
${ }_{\mathrm{m}}$ & 0.04 \\
$s_{\mathrm{mO}}(\mathrm{MPa})$ & 40 \\
\hline
\end{tabular}


Table 5. Parameters identified to characterise $S r_{\mathrm{M}}$ and $S r$.

\begin{tabular}{lr}
\hline$P_{\mathrm{M}}(\mathrm{MPa})$ & 8.70 \\
$l_{\mathrm{M}}$ & 0.73 \\
$P(\mathrm{MPa})$ & 26.58 \\
$l$ & 0.43 \\
\hline
\end{tabular}


Table 6. Parameters of the Barcelona Basic Model for the MX-80 analysed in this work.

\begin{tabular}{ll}
\hline Parameter & Value \\
\hline$K$ & 0.1 \\
io & 0.1 \\
i $(1 / \mathrm{kPa})$ & 0 \\
So & 0.05 \\
$\mathrm{Sp}$ & 0 \\
$\mathrm{SS}(1 / \mathrm{kPa})$ & 0 \\
$p_{\mathrm{REF}}(\mathrm{kPa})$ & 10 \\
$p_{\mathrm{C}}(\mathrm{kPa})$ & 0.35 \\
$(0)$ & 10 \\
$r^{(1 / \mathrm{kPa})}$ & 0.15 \\
$p_{\mathrm{O}}{ }^{*}(\mathrm{kPa})$ & 0.8 \\
$M$ & 1800 \\
\hline
\end{tabular}


Figure 1

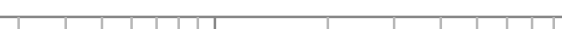

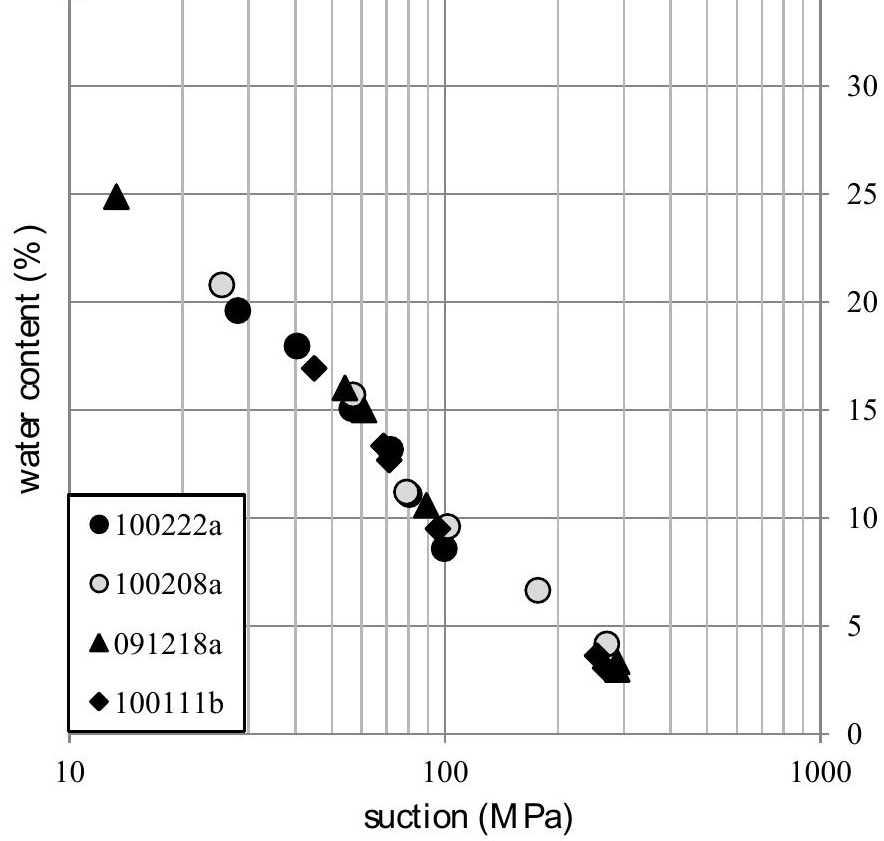


Figure 2

35

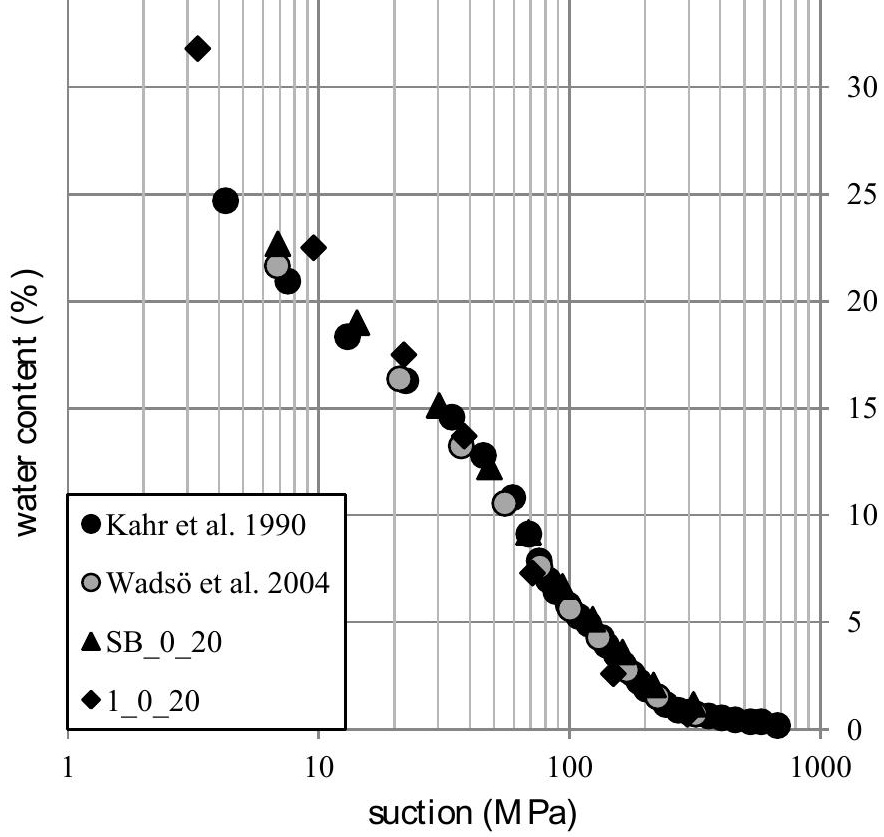


Figure 3

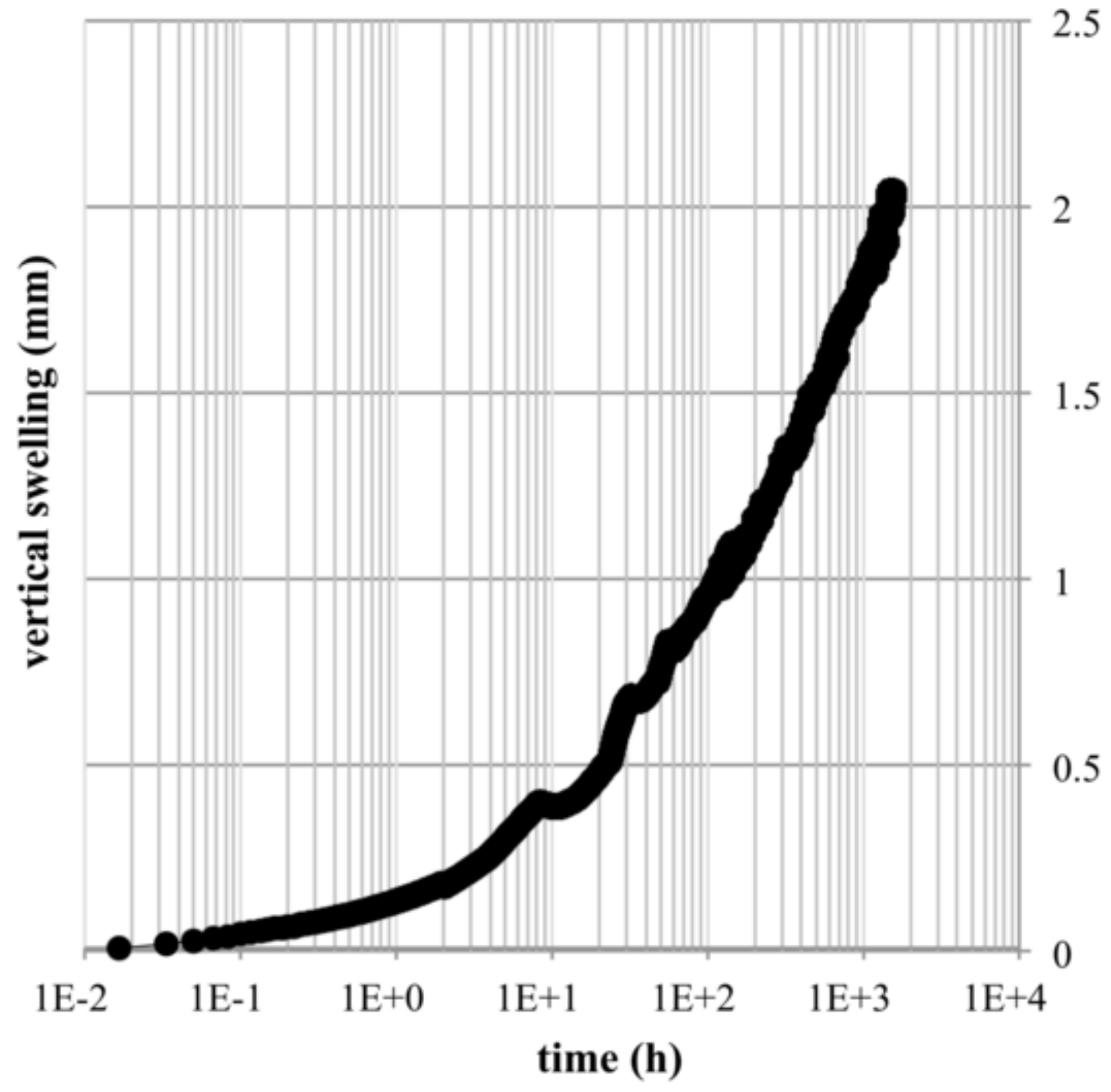


Figure 4
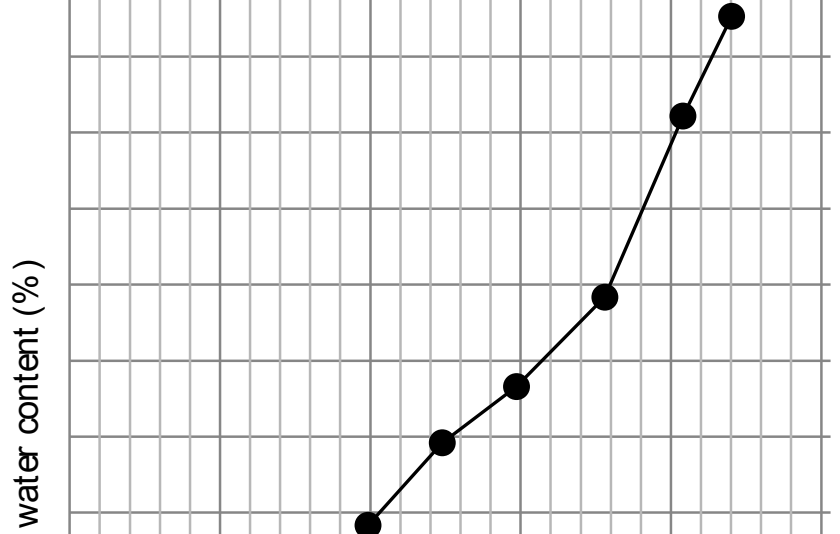

18

16

14

12

10

8

6

4

2

0

$\begin{array}{lll}0 & 0.2 & 0.4\end{array}$

0.6

0.8

1

$R H$ 


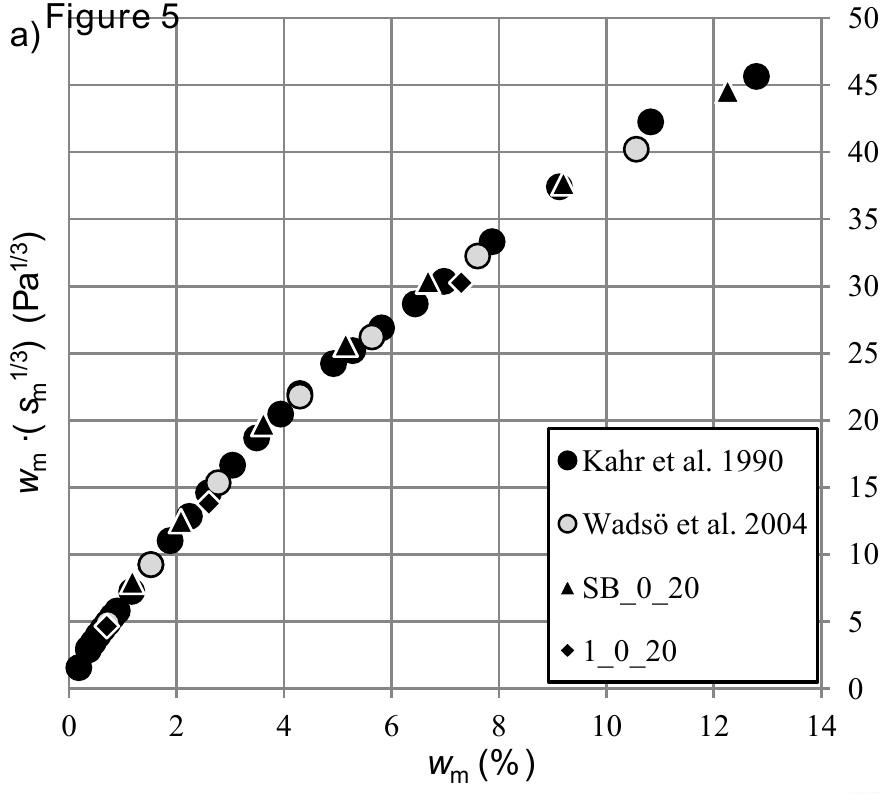

b)

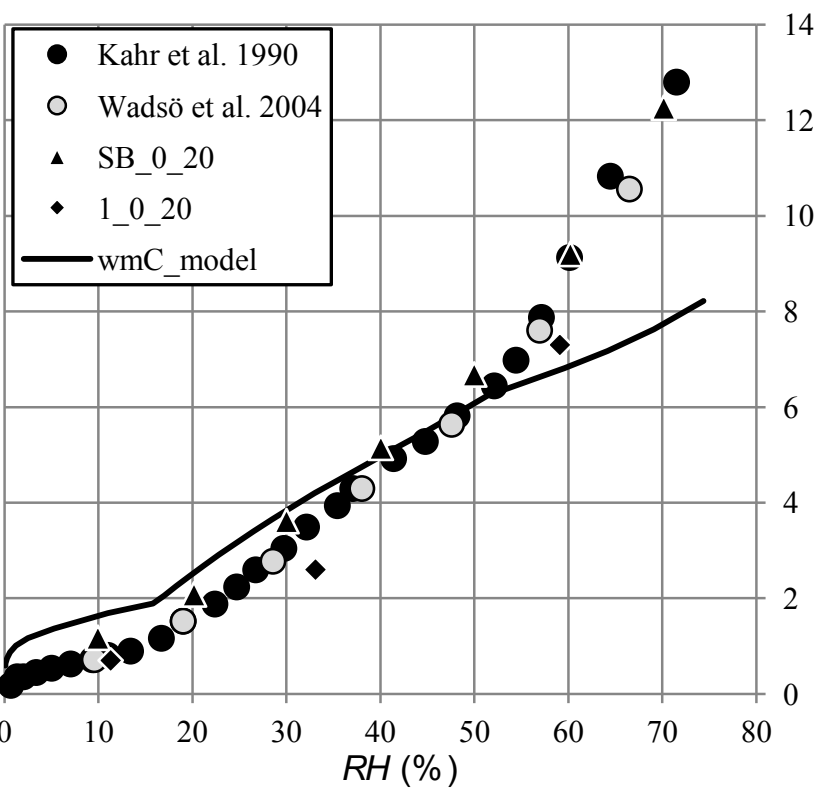

c

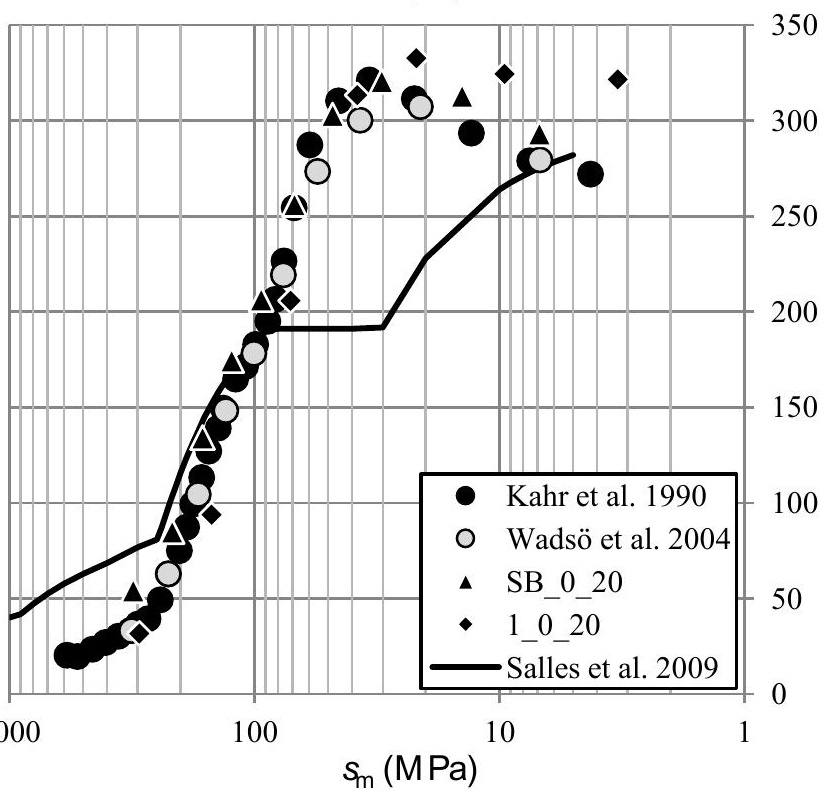




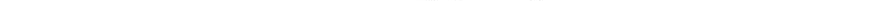




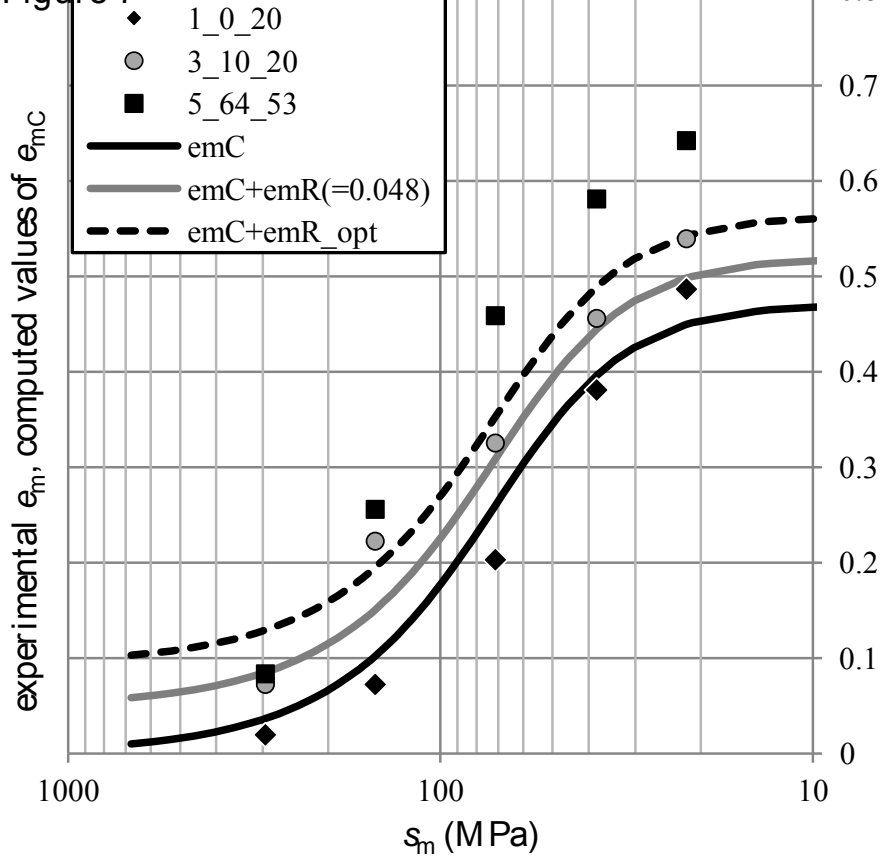

$s_{m}(\mathrm{MPa})$ 
Figure $\overline{10}$

100

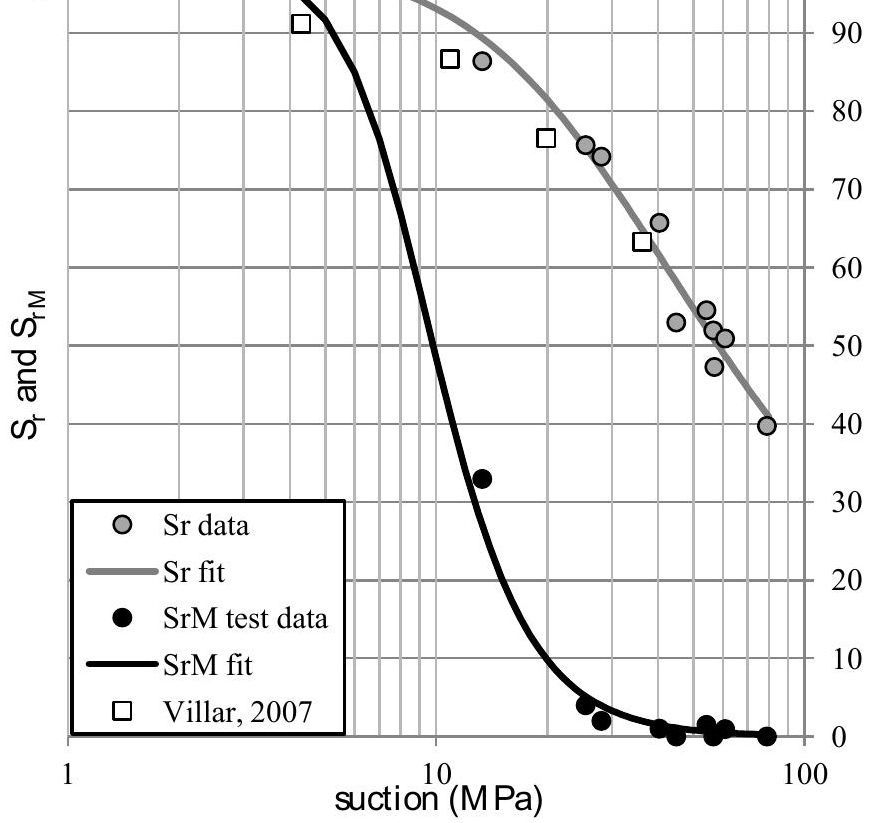


Figure 11

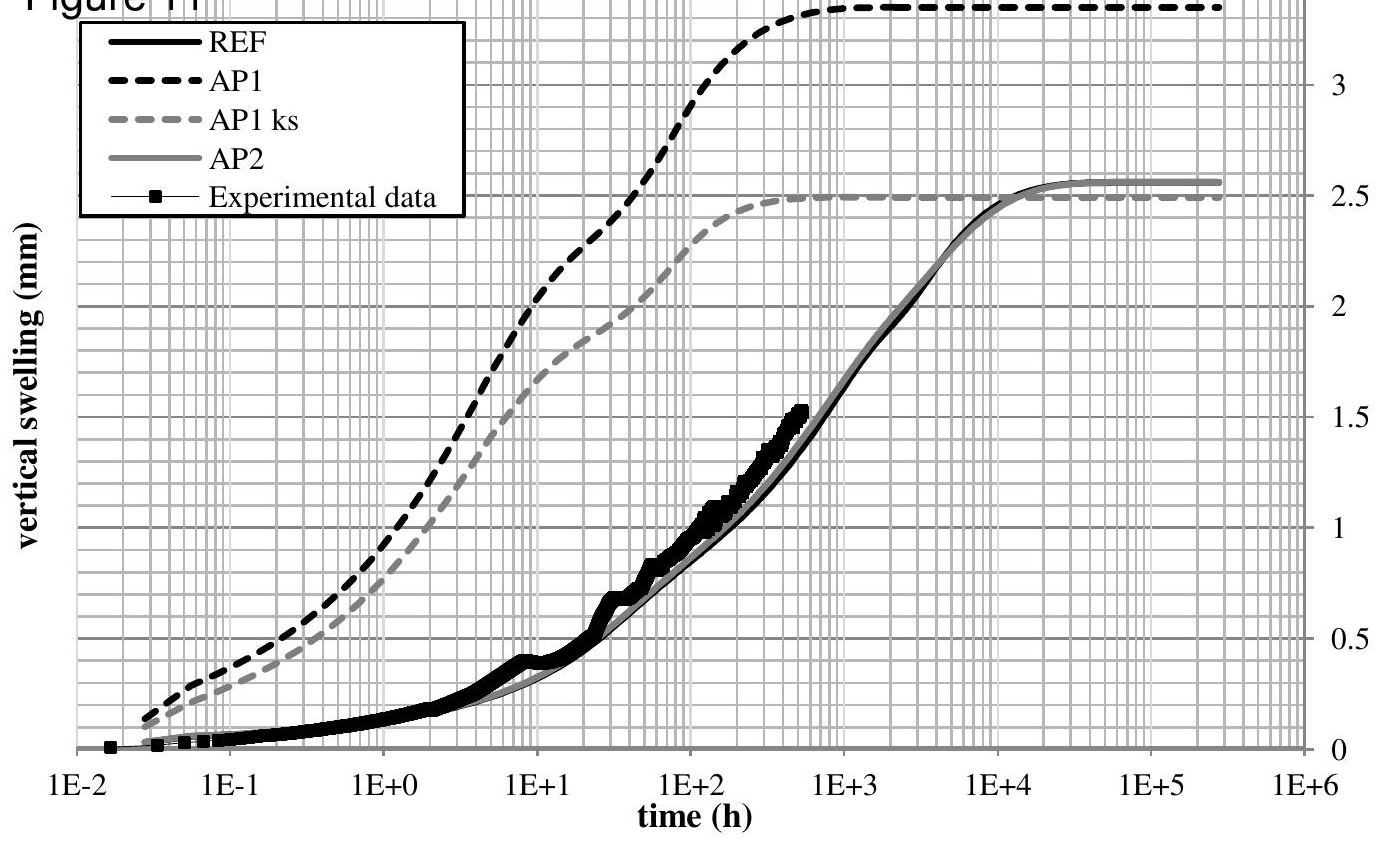




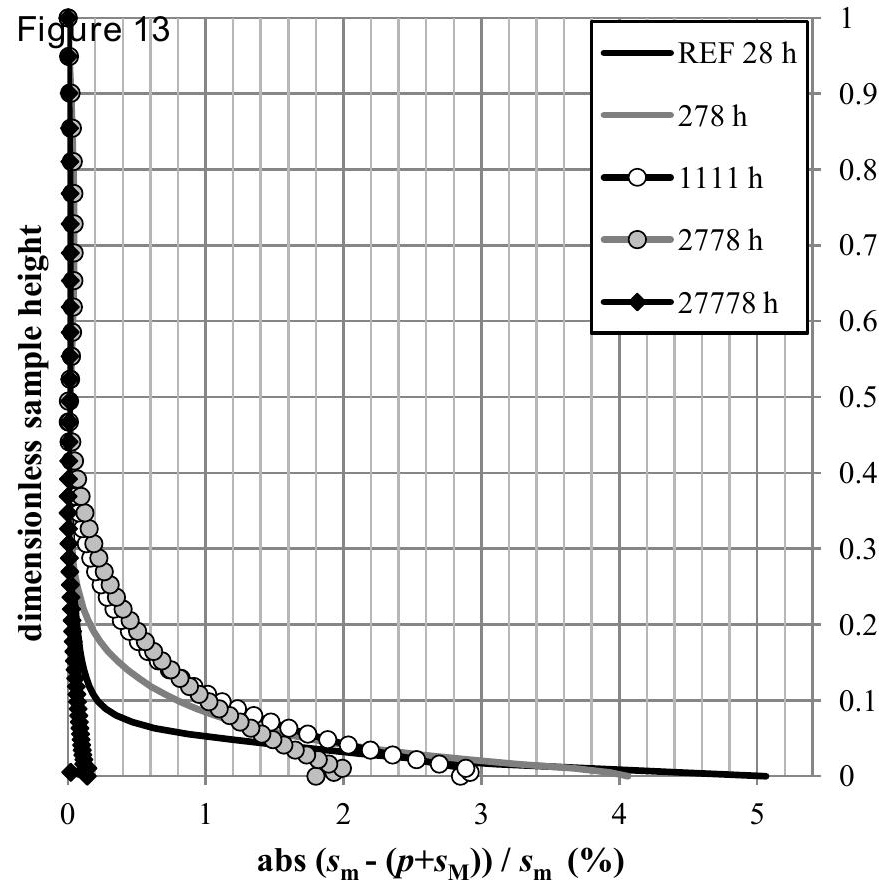




\section{Figure 14}


Fig. 1. Results obtained by B+Tech by applying the wetting paths described in Table 2 to the MX-80 characterised in Table 1 .

Fig. 2. Results obtained by Dueck and Nilsson (2010) (SB_0_20 and 1_0_20 tests), Wadsö et al. (2004) and Kahr et al. (1990).

Fig. 3. Vertical swelling results of the isotropic swelling test performed at the University of Castilla-La Mancha.

Fig. 4. Retention curve (wetting path) of a Wyoming bentonite, adapted from Cases et al. (1992).

Fig. 5. Data associated with suctions greater than $40 \mathrm{MPa}$ in Fig. 2 are used. (a) Relationship between the ratio $w_{\mathrm{m}} \cdot\left(s_{\mathrm{m}}{ }^{1 / 3}\right)$ and $w_{\mathrm{m}}$. (b) Comparison between the experimental values of $w_{\mathrm{m}}$ and values of $w_{\mathrm{mC}}$ (obtained by using Eq. 2 and the variation of $S$ presented by Salles et al., 2009). (c) Comparison between the experimental values of $S$ obtained from Eq. 2 and the variation of $S$ by Salles et al. (2009).

Fig. 6. Fit of $e_{\mathrm{mC}}$ values obtained with Eq. 15 to the experimental data from Fig. 2.

Fig. 7. Fit of the $s_{\mathrm{m}}-e_{\mathrm{m}}$ values obtained with Eq. 16 to the experimental data from Fig. 2.

Fig. 8. Fit of the $s_{\mathrm{m}}-e_{\mathrm{m}}$ values obtained with Eqs. 7, 8 and 15 to the experimental data from Fig. 2.

Fig. 9. Model (Eqs. 7, 8 and 16 and Table 4) and experimental $s_{\mathrm{m}}-e_{\mathrm{m}}$ values from the tests of Fig. 1.

Fig. 10. Test and model values of $S_{\mathrm{r}}$ and $S_{\mathrm{rM}}$ from the tests shown in Fig. 1 (dry densities shown in Table 2 were used). Data from Villar (2007) are also included.

Fig. 11. Experimental (Fig. 3) and model vertical swelling results associated with different calculation approaches. The results from the REF and AP2 approaches overlap.

Fig. 12. (a) Comparison of the macrostructural degree of saturation values obtained with the REF and AP2 approaches. (b) Relative difference in the macrostructural degree of saturation values obtained with the REF and AP2 approaches.

Fig 13. REF approach: difference between $s_{\mathrm{m}}$ and $p+s_{\mathrm{M}}$.

Fig 14. Evolution of the differences between the swelling strains obtained with the REF and AP2 approaches for different values of the transfer coefficient $H$. 